Policy Research Working Paper 1911

The Internationalization

of Financial Services in Asia

Stijn Claessens

Tom Glaessner
Asian countries should

consider the benefits of

opening their financial service

sectors more quickly-at the

same time that they are

liberalizing capital accounis

and deregulating domestic

financial markets

The World Bank

Poverty Reduction and Economic Management Network

Economic Policy Division

April 1998 
Policy Research Working Paper 1911

\section{Summary findings}

The internationalization of financial services eliminating discrimination berween the trearment of foreign and domestic providers of financial services and removing barriers to the cross-border provision of financial services - is of global interest, especially in Asia.

Most of Asia limirs the entry of foreign financial firms much more than otherwise comparable countries do. Empirical evidence for Asia and elsewhere suggests that this slows down institutional development and that, as a result, it costs more to provide financial services.

Asian countries could benefit from accelerating the opening of the financial services sector, in conjunction

with the further liberalization of capital accounts and domestic deregularion of financial markets.

Apart from other benefits, internationalization helps build more robust, efficient financial systems by introducing intemational practices and standards; by improving the quality, efficiency, and breadth of financial services; and by allowing more stable sources of funds.

The ongoing WTO negotiation of financial services under GATS gives countries the opportunity to commit to opening their financial sectors. Safeguards can be built into the process, and the liberalization can be phased in gradually.

This paper - a product of the Economic Policy Division, Poverty Reduction and Economic Management Network - is part of a larger effort in the network to study financial reform in developing countries. The paper was written during the summer of 1997 , before the East Asia financial crisis and before the conclusion of the WTO negotiations in December 1997. Copies of this paper are avallable free from the World Bank, $1818 \mathrm{H}$ Street NW, Washington, DC 20433. Please contact Rose Vo, room MC4-404, telephone 202-473-3722, fax 202-522-2530, Internet address hvo1@worldbank.org. April 1998. (58 pages)

The Policy Research Working Paper Series disseminates the findings of work in progress to encourage the exchange of ideas about development issues. An objective of the series is to get the findings out quickly, even if the presentations are less than fully polished. The. papers carry the names of the authors and should be cited accordingly. The findings, interpretations, and conciusions expressed in this paper are entirely those of the authors. They do not necessarly represent the view of the World Bank, its Executwe Directors, or the countries they represent. 


\title{
INTERNATIONALIZATION OF FINANCIAL SERVICES IN ASIA
}

\author{
by \\ Stijn Claessens \\ World Bank \\ and \\ Tom Glaessner \\ Soros Fund Management
}

Paper presented at the conference: "Investment Liberalisation and Financial Reform in the Asia-Pacific Region," August 29-31, Sydney, Australia, and at the conference: "India: A Financial System for the 21st Century," December 6-8, Goa, India. The paper was written while Glaessner was on the staff of the World Bank. We would like to thank a large number of people too numerous to mention individually in various agencies and private market institutions throughout Asia for their cooperation and information sharing, Jim Hanson, Leonardo Hernandez, Bernard Hoekman, Daniela Klingebiel, Chad Leechor, Philip Molyneux, Guy Pfeffermann, Edwin Truman, Zhen Kun Wang and Alan Winters for useful comments, Marinela Dado for her detailed analysis of the barriers and costs measures in Sections 7 and 8, and Catherine Downard for research assistance. The paper also draws on Claessens and Hindley (1997). The paper was written during the summer of 1997, before the East Asia financial crisis and before the conclusion of the WTO-negotiations in December 1997.

Correspondence: em: cclaessens@worldbank.org; Tel (202)-473-7212; fax: 522-2530. 


\section{Executive Summary}

The internationalization of financial services-eliminating discrimination in treatment between foreign and domestic financial services providers and removing barriers to the crossborder provision of financial services-is of global interest, but even more so for developing Asia. Many Asian countries limit entry of foreign financial firms much more than comparably developed countries. Asian countries are considering the issue of (further) opening up in the context of their general financial sector reform strategies and the Financial Service Agreement currently being negotiated under the GATS. This paper reviews the conceptual and empirical case for further opening up, studies the relationships between the openness of eight Asian financial markets and their institutional development and costs of financial services provision, and derives a number of policy implications.

Internationalization relates to the degree of capital account liberalization as it determines the potential gains and benefits from access to foreign financial services provided domestically relative to access provided and obtained off-shore. Internationalization also relates to domestic financial deregulation as the degree of regulation influences the quality and competitiveness of domestic financial services providers. A review of experiences suggest that almost independent of the state of development of the domestic financial system and the openness of the capital account, internationalization can help in the process of building more robust and efficient financial systems by introducing international practices and standards, by improving the quality, efficiency and breadth of financial services, and by allowing more stable sources of funds. Given the state of development of many Asian financial systems, these institutional benefits could be substantial. The review of experiences also finds very little support for the notion that foreign entry leads to more volatile capital flows or more difficult monetary policy management.

Cross-country empirical evidence for Asia specifically suggests that the limited openness to date has been costly in terms of higher costs of financial services, slower institutional development and more fragile financial systems. For eight Asian countries, the costs of financial services and the fragility of the financial systems are negatively related to the degree of openness of the domestic market to foreign financial firms. The efficiency of financial services provision and the institutional development of the financial sector are positively related to openness.

The review of evidence generally and for Asia specifically suggest that, going forward, Asian countries could substantially benefit from accelerating the opening up of their financial systems, in conjunction with further capital account liberalization, domestic financial deregulation, and a strengthening of the supervisory and regulatory framework and the role of the market in monitoring financial institutions. The ongoing financial service negotiations at the WTO provides countries with the opportunity to commit to this opening up, with built-in safeguards and the possibility of phasing in to minimize the possible adjustment costs. This commitment can be an important part of a country's overall financial sector development strategy, for which, given the regional financial turbulence, there may be a large premium today. 


\section{INTRODUCTION}

Many developing countries are assessing whether domestic financial-service sectors should be opened to foreign competition and, if so, how. Governments are interested in the questions of how fast to open up, in the design of policies to minimize transition costs and potential risks and maximize the benefits to their economies of increased openness, and in the required complementary policy measures. Countries in Asia have a special interest in this topic as many countries to date are closed compared to similar countries.

Introducing foreign competition in financial-services has come up as part of overall financial sector reform programs or in the context of regional trade agreements. More recently, the (resumed) negotiations on financial services in the General Agreement on Trade in Services (GATS), with a deadline of December 1997, have created another impetus to consider this issue as it involves countries making commitments to open their financial-service markets. And, as countries continue to review their policies towards foreign competition in their financial sector, internationalization will remain an important issue for the foreseeable future.

Analysis in this relatively new policy area requires an investigation of several related issues:

(a) a conceptual framework regarding the benefits and potential risks of (alternative ways of) opening domestic financial-service sectors to foreign competition (where such competition can take a variety of forms), the relationships of internationalization of financial services with capital account liberalization and domestic financial sector deregulation, and the complementary domestic policy measures and time-path needed to obtain the maximum benefits and minimum costs from opening up;

(b) the costs of providing financial services and the relationships between costs, the structure of domestic financial systems and related supporting infrastructure (e.g., telecommunications), and the barriers to entry by foreign financial services providers (FSPs); and

(c) the relationships between internationalization and the allocation of resources in and the performance of the real economy (e.g., the links between a country's competitiveness and the degree of openness of its financial sector).

The purpose of this paper is to review these questions for eight Asian countries. Section 2 provides the motivation and context. Section 3 reviews the relationship among various financial reforms, while sections 4 and 5 review the conceptual issues and the experiences with internationalization to date. Sections 6,7 and 8 respectively provide measures of the costs of financial services, the structure of financial systems, the institutional development and the degree of internationalization in eight Asian countries. Section 9 relates measures of financial sector efficiency, costs of financial sector provision, institutional development and fragility with the degree of openness for different financial services. The concluding section discusses the economic and financial policy implications of a process of further internationalization for Asia. 


\section{MOTIVATION AND CONTEXT}

Global trends in recent years include a process of more rapid financial integration and increased cross-border capital flows. Most Asian countries have actively participated in these trends and the bulk of private capital flows to developing countries has gone to Asia (World Bank, 1997a and 1997b). In recent years, Asian countries have also been in the process of deregulating their financial systems, albeit at different speeds, and allowing more access of foreign investors and financial service providers (FSPs) to their domestic markets. Table 1 positions the eight Asian countries of study in this paper in some of these dimensions. The table shows that these Asian countries are highly financially integrated and have experienced significant amounts of private capital inflows, much of it in recent years. While the share of domestic financial assets held by foreign-owned banks is relatively small, the share of foreign investors in stock market trading is quite large, with Indonesia the highest. Singapore's crossborder trade in insurance services is the highest among these countries, but in general these countries are not important exporters of financial services (as also reflected in the relatively small number of foreign branches of banks from these countries and the fact that many foreign firms established in these countries continue to use services from foreign banks).

Other global developments also affect Asian financial systems. Negotiation of a WTO agreement on international trade and investment in financial services - a post-Uruguay Round supplement to the General Agreement on Trade in Services (GATS) - was completed at the end of July, 1995. Most WTO members, but not the US, accepted the result.' Instead of a final agreement, the offers of other countries in the negotiation were therefore codified into an "interim agreement", and negotiations resumed in April 1997 with a date for completion of a final agreement set as of the end of 1997. Asian countries and other developing countries must therefore consider even more so their interests in opening their financial services markets to international competition in the context of their overall financial sector development strategies.

Although there are differences among Asian countries and their financial sector openness, a regional focus is useful. While Asian countries show a high degree of financial depth as reflected in the ratios to GDP of broad money, total banking assets, and private credit, relative to countries at their income levels, many Asian countries still have still quite regulated and institutionally under-developed financial sectors (Claessens and Glaessner, 1997). ${ }^{2}$ Asian

\footnotetext{
${ }^{1}$ The stumbling block for the U.S. was the obligation of signatories to the financial-services agreement (FSA) to provide most-favored-nation (MFN) treatment to other signatories-which implies that services and service providers from countries with closed markets for financial services must be treated in the same way as services and service providers from members with open markets. The U.S. was unwilling to accept this obligation when, in its view, the market access commitments of a number of developing-country participants were such that their markets for financial services in effect remained closed. The US, though, is not the only source of such pressure. Other developed countries want US membership of the WTO financial-services agreement, and will attempt to create circumstances in which the US will join. The EU in particular, which took the lead in arranging the interim agreement, is clear about its hope for a final agreement that is acceptable to the US.

${ }^{2}$ There are many forces already underway which put pressures on governments in the region to further liberalize and develop their domestic financial sectors: rapid changes in the real economies associated with high growth rates, including much more formalization and changes in the form of the corporate governance of firms (with a move Footnote continued
} 
countries also have relatively closed financial systems and Asian commitments to GATS were quite restrictive relative to the level of development of their financial sectors (Sorsa, 1997). And in terms of actual openness (as measured by the share of foreign assets in total banking assets), Asian countries, with the exception of Singapore and Hong Kong, rank low among emerging markets. These common features, and intra-regional deliberations regarding financial services (in APEC and ASEAN), ${ }^{3}$ warrant a regional focus.

\section{INTERNATIONALIZATION AND OTHER FINANCIAL REFORMS}

There are important linkages between internationalization of financial services and two other financial reforms: domestic financial deregulation, and capital account liberalization. In addition, there are important relationships between internationalization and the conduct of monetary policy. ${ }^{4}$ A definition of these three types of financial reform is as follows. Domestic financial deregulation allows market forces to work by eliminating controls on lending and deposit rates and on credit allocation, by reducing demarcation lines between different types of financial service firms (such as banks, insurance companies, stockbrokers), and more generally by reducing the role of the state in the domestic financial system. Capital account liberalization involves a process of removal of capital controls and restrictions on the convertibility of the currency. Internationalization of financial services eliminates discrimination in treatment between foreign and domestic financial services providers and removes barriers to the crossborder provision of financial services.

Internationalization and domestic financial deregulation The effects of deregulation of domestic financial markets has been an important policy issue for developing countries for some time. In the last decade, many countries in Asia have gradually deregulated their financial markets. The relationships between financial-market liberalization and economic development have been extensively explored; the results, including for Asia, indicate that liberalization of financial systems is a major factor in economic development, but needs to be carefully sequenced and managed (Caprio et al, 1994 and Levine, 1997). In particular, experience shows that it is vital to strengthen the supporting institutional framework, i.e., the regulatory and supervisory functions of the state (including the screening of the entry of new financial firms) and the use of the market in disciplining financial institutions (especially through better information and greater disclosure, and improved standards for the governance of financial institutions).

away from family-control and other forms of (social) controls to more formal corporate governance mechanisms, including through securities markets); large long-term financing needs, especially for infrastructure (power, roads, telecommunications, etc.) and housing, which can not be met by banking systems; and other domestic pressures, including a growing middle-class seeking a wider range of financial services. These issues are further discussed in Claessens and Glaessner, 1997.

${ }^{3}$ Such as the ASEAN Framework Agreement on Services, adopted December 15, 1995, which envisions free regional trade in goods and services in 2020.

${ }^{4}$ See Glaessner and Oks (1994) that highlight these links in the context of discussing the impact of internationalization under NAFTA. 
Internationalization and domestic deregulation are related, but not in any easy or straightforward way. Neither, for example, implies the other. A country might deregulate its financial system but still keep its financial markets closed to foreign competition. Japan, for example, has been deregulating its domestic financial system, but is still often singled out by other developed countries as being relatively closed to foreign FSPs. Or a country might over-regulate its domestic markets for financial services, but freely allow foreign financial firms to open local establishments and to compete with domestic FSPs within that system of regulation. Banking in the US, for example, is often criticized as over-regulated, yet US financial-service markets are very open to foreign FSPs. ${ }^{5}$

But the costs and benefits of internationalization of financial services will to a significant degree depend on the efficiency and competitiveness of the domestic financial system, which in turn will importantly be influenced by the nature of domestic regulation. Countries with a highly regulated domestic financial system may well suffer from inefficiencies and poor quality and breadth of financial services. Opening up to FSPs may then-in the short run--negatively affect domestic FSPs, not necessarily because foreign FSPs have unfair advantages (see further below), but because FSPs have been hindered in their development through regulations, have faced little competition, and have faced perverse incentives. At the same time, countries with poorly developed financial systems may benefit the most in the long run from opening up as it can accelerate financial sector development.

Internationalization and capital account liberalization Many countries, including in Asia, have relaxed controls on international capital movements in recent years, and have experienced significant capital inflows, and more recently net capital outflows. ${ }^{6}$ Research has generally found that reducing controls on international capital movements can lead to lower costs of capital and greater risk diversification (see Dooley 1996 for a review of the literature on capital controls). The quality of the financial system, however, is a central factor. Countries with weak financial systems, particularly in terms of supervision, have sometimes experienced financial distress following a period of rapid inflow of foreign capital associated with the earlier removal of controls on international capital movements (Honohan, 1997a, Goldstein and Turner, 1996, Mathieson and Rojas-Suarez, 1993, World Bank, 1997a).

Internationalization and capital account liberalization are related, but not in an obvious way. With an open capital account, equities issued in a developing-country market, for example, might be largely traded in New York in the form of an American Depository Receipt--but perhaps still owned by co-nationals of the original issuer. Or domestic firms may avail themselves of off-

\footnotetext{
${ }^{5}$ Even when countries deregulate, important differences in regulatory systems are likely to remain and influence the degree of competition in financial services when countries open up. Japan and the US, for example, maintain significant legal separation between commercial and investment banking. Banks and insurance companies are also kept separate for most purposes in these two countries. See further below.

- Capital account liberalization is a process and individual countries can be in different phases of this process ranging from fully controlled capital account to fully open. Asian countries span this range with China and India being quite controlled to Hong Kong being fully open. Even though being closed on the capital account, China has received large amounts of capital flows, mainly in the form of foreign direct investment.
} 
shore financial services: many Asian firms, for example, borrow abroad-and then repatriate funds in domestic currency for local use. Such cases involve both the movement of capital across borders and the use of foreign financial services, without the entry of foreign financial firms.

The degree of capital account liberalization can affect the costs and benefits of internationalization. First, capital account liberalization affects the incentives of foreign FSPs to establish presence in the country, as opposed to servicing clients from off-shore (which can include seeking business to be done off-shore through representative offices on-shore). Second, it determines the extent to which classes of domestic firms and individuals can already avail themselves of foreign financial services. Typically, as is the case for many Asian countries, with (largely) free capital mobility the largest and best credit firms and individuals will have access to foreign markets and internationally provided financial services, while smaller and less creditworthy firms and individuals will be confined to the domestic market. Third, it can imply varying costs across different users of financial services in the event of a financial crisis. If some of the cost of a financial crisis are passed on to the rest of the domestic economy (either through direct bailouts of corporates or support to financial institutions), ${ }^{7}$ then segmentation will (further) hurt other firms and consumers. Fourth, segmentation can affect the political economy of internationalization. Internationalization allows benefits for a wide class of firms and individuals, but firms and individuals which currently already have access to foreign financial services (provided off-shore) may be indifferent to internationalization. If those who do not have access to foreign financial service are politically less well-represented, then the political economy outcome could be a continuation of barriers to foreign FSPs.

Some degree of free capital movement will be necessary for effective and efficient internationalization. Some types of foreign (and domestic) FSPs need to be able to move capital across borders relatively freely to conduct their business efficiently. With limits on some forms of capital movements, distortions can easily be introduced. But, again, neither liberalization of the capital account nor internationalization is a precondition for the other. Capital might move relatively freely in and out of a country that maintains barriers against foreign firms providing financial services domestically. Many financial markets in Asia are still quite closed to international competition in financial services, even though these same economies have substantially relaxed their controls on capital movements in recent years. Chile, on the other hand, is quite open to foreign FSPs but maintains some controls on cross-border movements of capital. The key factor determining the optimal speed of capital account liberalization, however, appears to be the quality of the overall financial system, with the degree of internationalization more important indirectly-in terms of influencing the quality of the financial system-than in terms of directly affecting the optimal degree of capital account liberalization.

\footnotetext{
${ }^{7}$ In particular, much of access to international financial services will be denominated in foreign currency. This may create large currency mismatches, which in the event of a devaluation, can lead to large foreign exchange losses which can be passed on to other segments of the economy.
} 
Internationalization and monetary policy The conduct of monetary policy, including exchange rate management, may be affected by the degree of internationalization. Foreign financial firms may introduce new financial instruments, which may affect the behavior of money demand and make monetary management more difficult, particularly in countries which so far have relied more on direct monetary policy instruments. Concerns about the behavior of foreign banks in the host country moving capital rapidly across borders have also been mentioned. And the presence of foreign banks may allow firms and individuals to move funds more easily in and out of the country. This could make monetary policy more difficult as well as create opportunities for (more) private capital outflows ("capital flight"). Many of these concerns relate to financial innovation and monetary management more generally, but internationalization can be expected to expand the class of instruments and the number of firms and individuals engaged (directly or indirectly) in more rapid asset substitution, including through capital account transactions.

Internationalization also raises important issues regarding the taxation of (cross-border) provision of financial services. Some developing countries still impose heavy direct and indirect taxes on their financial system, including through reserve requirements. Internationalization, however, can imply larger cross-border capital flows which will be more difficult to tax. When the tax system is not rationalized, asymmetries and distortions can also more easily arise with internationalization. The process of internationalization forces thus a need for lowering the taxation of the financial system and reforming the taxation of financial services.

Complex Relationships The relationships between internationalization, domestic deregulation, capital account liberalization and monetary policy are thus complex (Glaessner and Oks, 1994, provide a more extensive discussion; see also WTO, 1997). At present, a tightly defined theoretical and conceptual structure for analyzing the impact of these related issues is still missing and empirical evidence is only starting to become available. It is thus too difficult to discuss issues such as the optimal speed and other relationships between the three types of reform. It appears, however, that there is not a unique optimal sequence to these reforms: experiences as diverse as Indonesia (rapid capital account liberalization followed by gradual internationalization), Chile (slower capital account liberalization but more rapid internationalization) and the US (slower deregulation in the provision of financial services by different types of financial firms, but free entry) show very different approaches but no clear differences in impact (in terms of, for example, efficiency and enhancing competitiveness of banking system, speed of financial reform, or more generally, economic welfare) ${ }^{8}$

There also does not appear to be an obvious optimal sequence for a given level of development. In a low-income country with good growth prospects, but with a poorly developed financial services industry, for example, there are many reasons to expect that opening up to foreign FSPs will lead not only to improved financial services, but also to a more stable capital

\footnotetext{
${ }^{8}$ It will be difficult to explain separately the effects of these financial reform processes for a certain country. Even in stable, developed countries it has been difficult or impossible to assess the impact of various financial systems (in current use or even in recent history) on the economies.
} 
account. ${ }^{9}$ In a middle-income country with a highly-developed financial system, but with significant non-performing assets, however, internationalization may well need to be phased to deal with the adjustment costs. Any approach, of course, needs to be internally consistent and the various reform processes need to be supported by a strengthening of the institutional framework for the financial sector.

The relationships between the various reform processes may also differ by type of financial services. Non-life insurance services (e.g., motor insurance) and many other consumer financial services, for example, have mostly non-financial services' characteristics: they involve, for example, few investable funds. They thus have fewer linkages with capital account liberalization and monetary policy, and internationalization of these services might proceed more independently of other financial reform processes. The high degree of substitutability between the various financial services (for example, life-insurance contracts can have features equivalent to bank deposits), however, make a refined differentiation for other services difficult in practice and possibly unproductive.

\section{CONCEPTUAL FRAMEWORK AND COST AND BENEFITS}

The starting point for the study of internationalization of financial services is whether the theory of comparative advantage and the empirical evidence on the benefits of openness developed for trade in goods applies to trade in services. The general conclusion of research on this topic is that the broad conclusions of comparative-advantage theory hold also for servicesand thus that internationalization of services has large potential benefits for developing countries as they are comparatively less well-endowed-but require modification in the detail of the analysis to take account of the differences between goods and services (see Hindley, 1996a for a review). Internationalization of financial services, however, is a much more recent field of study and has been studied much less systematically. ${ }^{10}$ Most of the papers in this area are also based on first principles often derived from the analogy with liberalization of trade in goods (and only to a very limited degree on empirical evidence). ${ }^{11}$

\footnotetext{
${ }^{9}$ In this respect, it is useful to recall that in the past many developing and now developed countries' financial systems were dominated by foreign FSPs without apparent adverse affects on financial flows. Under the goldstandard and further back in time, financial services were transacted through a limited number of internationally operating FSPs or individuals (e.g., the Rothshilds of the world).

${ }^{10}$ Sagari, 1988, 1989, discusses internationalization of financial services specifically and derives the result that skilled labor can be the source of comparative advantage in the production of financial services. Gelb and Sagari, 1990 , discuss the case of multilateral negotiations in financial services specifically. They argue that developing countries should open their borders to foreign competition, but at a moderate pace. Several other papers have made the general conceptual case for internationalization of financial services (Walter and Gray, 1983, Walter, 1987 and 1993, UNCTAD, 1994, and Levine, 1996). Glaessner and Oks, 1994 and Musalem et al. 1994 present a case in the context of NAFTA; WTO, 1997 reviews the literature and issues as well.

"One exception is Moshirian, 1994, who shows empirically for 13 OECD countries that the supply of international financial services depends on national R\&D, banks' international assets and physical and human capital, thus suggesting that comparative advantages are important in the delivery of financial services.
} 
International transactions in goods and international transactions in services-especially in financial services-differ, however, in two important ways from other forms of trade which need to be taken into account. First, provision of services often requires the provider of the services to have a local presence. Efficient provision of financial products often requires information that is difficult to obtain from a foreign location - detailed information to tailor loans or other financial services to client characteristics, for instance, or the ability to offer advice that requires knowledge of local conditions. If financial services are "imported" through the locally-established branch or subsidiary of a foreign FSP, then local firms can only be protected against competition by entry barriers. Other forms of barriers (e.g., higher taxes on foreign financial services) will then not be a equivalent measure, as tariffs can be in the case of trade. Because trade in services is more difficult to observe and monitor, regulators may actually require domestic presence to ensure that they maintain control (many countries do so, for example, for the solicitation of insurance services). ${ }^{12}$

Second, the provision of financial services is typically highly regulated, for both fiduciary and for monetary-policy purposes. The case for such regulation is universally accepted and is not at issue when it comes to the internationalization (for example, under the WTO any prudential measure is explicitly excluded). Regulation, however, affects the cost of providing a service. Hence, when FSPs subject to one set of regulations compete with FSPs subject to another, one element in the outcome of the competition is the relative cost of complying with the different regulatory systems. Differences in regulations between countries may thus affectfairly or unfairly-competition in trade of services across borders as well as the local provision of financial services by foreign (regulated) firms. ${ }^{13}$ And undue regulations risk of course distortions and may limit the efficiency gains of entry by foreign financial firms.

Benefits The main conclusion of the conceptual papers is that, as the removal of barriers to trade in goods allows for specialization according to comparative advantage and can lead formerly-protected producers to improve their efficiency, so can foreign involvement in markets for financial services lead to an improvement in the overall functioning of domestic financial systems. Levine, 1996, who surveys these issues and the existing literature on internationalization, identifies three specific potential benefits: (a) better access to foreign capital; (b) better domestic financial services; and (c) better domestic financial infrastructure (including improved regulation and supervision), with the last two the most important benefits of internationalization for developing countries (Glaessner and Oks, 1994, provide a similar account in the context of NAFTA).

12 The advent of electronic provision of financial services (e.g., through the Internet) has brought this to the forefront not only in the cross-border provision of financial services, but also within countries (e.g., see the discussion in the US on the use of electronic money).

${ }^{13}$ On this basis, it is said that national markets for financial services cannot be internationalized until national regulatory systems have been harmonized. An alternative view is that international competition will put pressures on regulators to deregulate, and possibly harmonize, and that internationalization should not be held hostage to attempts to harmonize. This latter view can be found in Glaessner and Oks, 1994, and William White, 1996a. 
The specific benefits that countries might expect in these last two areas include: a more efficient financial sector; a broader range and improved quality of (consumer) services; better human skills; pressures for improved regulation and supervision, better disclosure rules and general improvements in the legal and regulatory framework for the provision of financial services; improved credibility of rules (as the country enters into international agreements and intensifies linkages with foreign regulators, thereby lowering the risk of policy reversals); and a reduction in (systemic) risks and improvements in (stock market) liquidity. These benefits of internationalization can follow both through top-down actions on the part of government and through bottom-up pressures from the markets as best international practices and experiences are introduced and competitive pressure increases.

As in other sectors, openness to foreign competition allows consumers to obtain better and more appropriate services more cheaply and puts pressure on domestic financial firms to improve their productivity and services. It also allows financial firms access to technologies and ideas to help them raise efficiency. Opening up can thus help countries build up an export sector in financial services, an expressed desire of some Asian countries. Internationalization will also put pressures on improved supervision by authorities of domestic financial institutions. The presence of foreign FSPs can further help improve the screening of projects and monitoring of firms, thus leading to a better financial system. The most important benefits of an open financial system will likely stem from the positive spill-over effects on savings and investments and on the allocation of productive resources, which would translate into positive effects on economic growth. The general relevance of a good financial system for growth ${ }^{14}$ and the mechanisms through which this occurs are well established (see Levine, 1997 for a review).

Costs Specific evidence on the costs of internationalization is needed once one considers the relationship between internationalization and deregulation. Deregulation suggests a desire to improve the efficiency of the system; but, if that is the objective, why exclude international competition? In other type of industries, international competition is regarded as the best guarantee that domestic producers are, and remain, efficient. The answer to this asymmetry between domestic deregulation and internationalization mainly relates to the desirable relative speed of internationalization and lies in both economic and political economy arguments.

Economic arguments Economic arguments against rapid internationalization are based upon adjustment costs. Costs often mentioned are the following. First, the ability of domestic institutions to monitor a more complex financial system may be limited (as a consequence of, for example, a poor legal framework, a lack of the skills needed for supervision, and poor market discipline). In the light of such problems, too rapid internationalization may lead to larger (systemic) risks as foreign FSPs can not be supervised and monitored properly. Related, the government may lack credibility in enforcing prudential regulations and withdrawing an

\footnotetext{
${ }^{14}$ In a seminal piece of work, King and Levine, 1993, use a cross-country sample of 80 cases over the period 1960-1989 to show clear and convincing links between growth and finance and also to provide strong evidence that better developed finance precedes faster growth, after controlling for a variety of other factors (including income, education, political stability, and monetary, fiscal, trade and exchange rate policies).
} 
(implicit) insurance scheme, and as a consequence it is reluctant to reduce controls on financial system and open up to foreign entry as it expects that liberalization will lead to excessive risktaking at the final expense of the government. Also significant participation of foreign banks in a country's payment system has been argued to possibly lead to adverse effects.

Second, in cases where the financial system is currently undercapitalized, rapid entry could lead to (more) financial distress among domestic FSPs as profits decline. In particular, the presence in the banking system of large non-performing loans may require policies to maintain higher profits (higher franchise value) for existing banks, and therefore call for restrictions on the entry of new banks (both domestic and foreign). ${ }^{15}$ Third, regulatory advantages possessed by foreign banks, which could make competition between domestic and foreign banks unfair, especially as emerging markets have special features. It might, for example, be useful to impose more stringent regulatory requirements in emerging markets than those imposed in more advance economies (due, for example, to the higher risks faced). Admitting financial firms chartered and supervised in other countries would then create an unlevel playing field from the standpoint of domestic financial institutions. And fourth, the infant industry argument for protection, and relatedly possible adverse effects on domestic labor in the financial sector, have been mentioned.

Many of the arguments mentioned, even if valid, do not necessarily require limiting entry to foreign FSPs (or limiting the cross-border provision of financial services), or at least do not require considering domestic deregulation and internationalization separately. The presence of large, non-performing loans, for example, can in principle be dealt with through restructuring of individual financial institutions or through specific taxes on financial services, rather than through limiting entry. The infant industry argument against international competition has been tested and found wanting when liberalization of trade in goods is at issue. Even where its premises can be shown to provide a valid basis for intervention, it is easy to show that other forms of intervention are economically superior to barriers to imports An unlevel playing field could be corrected by requiring foreign financial firms to observe the same regulations as domestic financial firms, i.e., national treatment. The integrity of the payments systems can be assured by adopting clear rules on the quality and integrity of financial institutions which can participate. And the effect of internationalization on domestic labor is likely to be limited as relatively little labor is employed by the financial sector, especially in Asian developing countries, as foreign FSPs will tend to employ nationals when they establish local presence and as, in any case, the effect is no more so than for labor from other sectors experiencing efficiency gains.

These economic arguments do not apply similarly to all financial services. While there may be a case for gradual internationalization of some bank-based financial services, this is not necessarily the case for some of the other non-bank-based financial services. There are few economic reasons why for example, non-life insurance services (e.g., car insurance) would have

\footnotetext{
${ }^{15}$ Similar arguments are used for other type of financial services, for example, insurance. The issue is not the relevance of franchise value for financial sector stability, reviewed by Caprio and Summers, 1993, but rather the aim to shore up a financial sector through restricting entry excessively instead of encouraging exit and restructuring.
} 
negative effects on financial sector stability and thus can not be internationalized rapidly. These services have few linkages to monetary policy and rules to assure consumer protection, rather than prudential regulation, will be important. Furthermore, since these services tend to be less developed in most developing countries, opening up will have little negative effects on domestic FSPs.

Political economy arguments International competition, it is said, will eliminate local FSPs, and thus leave the domestic financial system at the mercy of foreigners. Furthermore, it is claimed, foreign banks will operate only in very profitable market segments; will have no commitment to the local market, and may contribute to capital flight. International competition must therefore be regulated, impeded and limited. These arguments are mainly put forward by interested parties standing to lose from opening up. As in the case of trade reform, e.g., tariff reductions, there will be fierce opposition by interested parties to opening up (which sometimes may include foreign financial firms already established). In part, the political economy arguments also arise from the notion that foreign domination of the domestic financial system must be avoided. National security and cultural integrity demand barriers to foreign competition.

The validity of these arguments is subject to debate. Most importantly, it should be clear that openness to foreign competition puts pressure on domestic financial firms to improve their productivity and services which is beneficial. Furthermore, the goal of authorities cannot be to maintain all financial institutions at all times: system stability rather than individual stability is what matters, and the exit of insolvent financial institutions is a necessary discipline.

Nevertheless, if there is to be intervention to ensure the survival of local FSPs-for economic or political reasons, the question needs to be answered whether alternative means of ensuring the survival of local FSPs exist and which of these is preferable? The analysis of trade has come up with some means which are more efficient than simply restricting trade, e.g., subsidies to local firms or taxes on foreign firms, or, if there are to be entry barriers, the auctioning of licenses. In principle, more efficient instruments could also be used temporarily in the case of financial services, with a view of eventually eliminating them. ${ }^{16}$ But temporary measures can have disadvantages which, similarly to the case of trade, largely stem from moral hazard and political economy reasons. Temporary subsidies to local FSPs may in principle allow them to prepare themselves to face international competition, but they can become a too powerful additive which can no longer be taken away. These risks appear to be larger with financial firms than with manufacturing firms and providers of other type of services as there often will be a greater (explicit or implicit) safety net already provided by the government for FSPs, making withdrawal of support in the future even less credible. Auctions may not attract

\footnotetext{
${ }^{16}$ Under the GATS-rules, laws and regulations may be applied differently to foreign FSPs, provided that their effect is equivalent in granting de facto national treatment and does not place foreign FSPs at a competitive disadvantage in the host country market. And GATS allows of course countries to schedule derogations from market access/national treatment. If a country has quantitative restrictions and has made an exception for them, it can therefore maintain differences in treatment between foreign and domestic FSPs (see further Hoekman and Sauve, 1994).
} 
the best qualified bidders in case of financial services as there is more room for adverse selection. ${ }^{17}$

\section{REVIEW OF EXPERIENCES WITH INTERNATIONALIZATION}

Benefits Until recently, there were only a few studies on the costs and benefits of internationalization of financial services. Bhattacharya, 1993, surveys experiences in Pakistan, Turkey and South Korea and finds that foreign banks helped to make foreign capital accessible to fund domestic projects. Pigott, 1986, reviews the experiences of nine Pacific Basin countries specifically and provides some aggregate statistics on the size and scope of foreign banks activities. He finds that while foreign banks rely more than domestic banks on foreign borrowing, foreign banks still fund more than $3 / 4$ of their domestic loans from domestic sources. McFadden, 1994 provides a study of the effect of removal of restrictions on foreign FSPs in Australia and finds that this has led to improved domestic bank operations. Using aggregate accounting data for 14 developed countries, Terell, 1986, finds that countries which allowed foreign bank entry had lower gross interest margins, lower before-tax profits and lower operating costs (all scale by the volume of business). There have also been some studies on the potential impact of regional trade agreements (which comprise major internationalization of financial services), most notably for the EU, EU/Price Waterhouse, $1988 .^{18}$

Now, specific empirical evidence of the benefits of internationalization is starting to accumulate, particularly on the ex-post impact of opening up in the context of regional agreements (Honohan, 1995, on the effects in Ireland, Portugal, and Greece; Honohan, 1997b, on Portugal, and Greece; Vasala, 1995, EU, 1997, Gardener, Molyneux and Moore, 1997, and other related papers on the effects in the EU; Nicholl, 1997, on New Zealand; Arriazu, 1997 on Argentina; Pastor, Perez, and Quesala, 1997, on Spain). White, 1996b, reviews financial sector issues for 15 small open economies. It considers the impediments to liberalization; strategic issues of reform; some practical issues (related to monetary policy, money and capital market developments) and the benefits of foreign financial firm presence. These studies generally find that opening up has led to improvements in local institutions and standards, that open financial systems are more contestable and more efficient and have better services (box 1).

These beneficial effects appear to occur at low increases in the presence of foreign FSPs. In Argentina, for example, the ratio of operational costs to assets declined from $1.3 \%$ in 1990 to $0.5 \%$ in April 1997, while during the same period the share of total assets held by foreign banks only rose from $15 \%$ to $22 \%$ (Arriazu, 1997). ${ }^{19}$ The banking system in Colombia has low levels

\footnotetext{
${ }^{17}$ Guash and Glaessner (1995) analyze the issue of bidding for credit lines, which has some analogous features.

18 Other ex-ante studies include for the Canada-US FTA, Swedlove and Evanoff, 1992, Sauve and Gonzalez-Hermosillo, 1993; and for NAFTA, Musalem et al. 1994, and Glaessner and Oks, 1994. Wang, 1995, and Borish et al. 1996 review and assess the progress of central European countries in preparing their financial sectors for integration with the EU.

19 This is corroborated by Dick (1996) who finds that X-inefficiency levels for Argentine banks declined significantly over the 1991-1994 period, due to increases in competition as a result of deregulation and growth.
} 
of foreign ownership, about $4 \%$, yet the marginal costs of providing banking services has declined substantially as financial reform, including allowing more entry, progressed (Barajas, 1996). And for the EU, while the announcement and implementation of the Single Market Programme (SMP) led to a dramatic shift in the strategic focus of banks in all countries towards competition and an increase in cross-border mergers and entry through new establishment, the expected widespread increase in foreign bank ownership of domestic banking firms has not materialized (Gardener, Molyneux and Moore, 1997a and 1997b).

There is much anecdotal evidence that foreign FSPs introduced new financial products and enhanced the quality of existing services, and spurred improvements in the quality of the institutional framework. In many countries, for example, foreign FSPs have started new consumer financial products, initiated the development of local bond markets and initiated assetbacked securities programs. In the Philippines, foreign companies have led to improvements in insurance services. Throughout the developing world, one can find bankers who have formerly worked in foreign financial firms as indicators of beneficial spill-overs.

The experience in the US with financial deregulation is also relevant. Banks in the US have been subject to extremely severe entry barriers in the form of branching restrictions. Traditionally, banks were regulated across state lines and until the 1980s were unable to cross county lines in many states as well. As a result, the US banking industry has been extremely segmented with thousand of banks and bank holding companies. Jayaratne and Strahan (1996) study the effects of the lifting of some of the inter-state and inter-county restrictions on bank expansion, a policy very similar to liberalizing the establishment of FSPs across borders. They find that banks' profits increase and loan quality improves after states permit statewide branching and interstate branching. They also find evidence that more competitive banking markets - following deregulation-better discipline bank managers, thereby further improving bank performance. 
Box 1: Recent Experiences with Internationalization of Financial Services

The effects of the 1992 Single Market Programme (SMP) has been recently reviewed in a number of studies (EU, 1997), with three studies on the financial services sectors in the EU. The major finding of the study on banking markets and credit sector (Credit Institutions and Banking) was that the SMP has made a substantial contribution to the restructuring of European banking markets and has contributed to the increased influence of external market forces on banking strategies throughout the EU. Particularly large effects were observed in those markets which had experienced less financial sector reform, such as Greece, Italy, Portugal and Spain. While a number of barriers still remain which restrain the exploitation of the full benefits of the EU, changes to date have facilitated more competitive banking systems. Especially retail loan and mortgage pricing in Greece, Italy, Portugal and Spain improved. Consumers are benefiting from a wider range of financial services and new channels of delivery have opened up. The SMP has also led to the further realization of economies of scale and greater opportunities for exploiting economies of scope. There has been no strong evidence that, in response to the SMP, banks have changed strategies in ways that threaten the stability of banking systems in the EU.

Reviews of the specific experiences of Greece, Ireland and Portugal (Honohan, 1995 and 1997b) show that domestic deregulation was probably more important than internationalization in reforming their financial sectors and leading to a large expansion in financial services. In all countries, however, EU-entry triggered and accelerated this domestic deregulation and reform. Initially banking margins increased, as banks were freed from interest controls and regulated lending. As competition increased, however, margins subsequently fell and services, particularly for consumers, improved in quality and breadth. While the number of foreign FSPs which entered was substantial, their actual market penetration remained remarkably limited. In the short-run, domestic FSPs lost some market shares, but, the increased competition also spurred greater efficiency with downward trends in staff costs.

An experience particularly interesting is that of Spain. The Spanish banking system was traditionally a highly regulated one, characterized by a lack of foreign competition, significant investment and reserve requirements, and the domination of large banks (Vives, 1990). The onset of the liberalization process in Spain occurred in the early seventies with the relaxation of limits on entry and branching and the freeing of interest rates, but suffered in its progress early on. During the period of 1978 to 1985 , a banking crisis erupted that was in part the result of large banks having strong interests in industries which suffered heavily from the oil shock and general bad management and poor monitoring. Following the crisis, the process of financial sector reform in fact accelerated with the entry into the EU. Increased competition, lower margins and operating expenses, an increase in financial intermediation, and improved management within the banking sector resulted by the mid-1990s. Concentration increased, but market power declined, and quality of services improved. While there was much merger and acquisitions activity, actual entry by foreign financial firms remained small (see further Pastor, Perez, and Quesala, 1997).

For Mexico, NAFTA triggered internationalization of financial services, with a further acceleration following the December 1994 crisis. This has involved more foreign investment in the financial sector since 1995, with 16 newly-chartered foreign banks and two large banks now majority foreign controlled, and about $18 \%$ of the banking system is now in foreign hands, compared to about $1 \%$ prior to 1994 . This also has had a stabilizing influence on capital flows. The agreement also had a significant impact on reducing the tendency for policy reversal during the financial crisis.

For many countries, the effects of allowing greater foreign entry appears to be foremost in terms of increasing the number, rather than in greatly expanding the share of the market of foreign FSPs. The beneficial effects on the contestability of the domestic market also appear to be a function of the relative number of banks, rather than their size of the market. Claessens, Demirguc-Kunt, and Huizinga, 1997, for example, using data on individual bank balance sheets and profit statements of 80 countries (of which more than 50 developing countries and transition economies) over the period 1988-95-leading to about 7900 individual bank operations, find that it is the number of foreign banks, rather than their share of the domestic market, which is negatively correlated with domestic banks' profitability and overhead expenses. 
The effects of internationalization and capital account liberalization and monetary policy has also been considered. In some countries, for example, New Zealand, the financial system is largely in the hand of foreigners, without any adverse affects on monetary policy or more volatile capital outflows (Nicholl, 1997). There is also little evidence that foreign firms do not have the commitment to the local market. In New Zealand, so far as is evident at present, there have been no adverse affects on the access to financial services by various agents. Provided the playing field is level, that little reasons to expect that foreign financial firms would not be willing to provide financial services across a broad section of the economy and instead would operate only in the most profitable segments. If gaps in service are a problem, nevertheless, foreign firms, like domestic firms, can be encouraged to provide financial services in less profitable market segments through explicit subsidies or regulations. There is also evidence for the US that foreign FSPs do not just follow firms from their home countries, but do allocate a significant share of their business to non-home, i.e., host-country borrowers (Nolle and Seth, 1997), thus generating beneficial spillovers. ${ }^{20}$ Wengel (1995) studies the trade flows in banking services among 141 countries using information on more than 3600 banks which operate internationally. He finds, among others, that the relaxation of exchange and capital controls by potential host countries diminishes the incentives of banks to seek direct representation, thus confirming the substitution links between capital account liberalization and internationalization.

The argument that internationalization will lead to large capital outflows appears questionable. The experiences of capital flight from many developing countries in the 1970s and early 1980s under circumstances with significant capital controls and very limited presence of foreign banks clearly demonstrate that foreign banks are not the main cause and that capital controls can not limit capital flight. Rather the causes underlying capital flight are typically poor and inconsistent policies, political uncertainty, and high and variable taxes that make the domestic market an unattractive and risky place to invest in (see Claessens, 1997 and Schineller, 1997, for recent work). More generally, disintermediation and dollarization is mostly a function of the degree of domestic financial repression than of the degree of capital account liberalization. Presence of foreign financial firms is more likely to reduce capital flight, as was observed in several recent episodes (e.g., in Argentina and Thailand foreign banks received large amounts of deposits from domestic banks when concerns arose about the quality of domestic banks).

Costs and Risk Some questions on costs and potential risks of foreign entry have been addressed in the literature on experiences with internationalization. It is clear from the experiences of the EU and NAFTA that regulation that is justifiable in terms of fiduciary or monetary-policy concerns can be distinguished from regulation that is primarily motivated to protect domestic FSPs. And specific monetary policy concerns can be dealt with through traditional monetary policy instruments or capital controls (Nicholl, 1997). Most developed and some developing countries allow for free entry of foreign FSPs without any adverse effects on

\footnotetext{
${ }^{20}$ On the other hand, it has been found for the US that binding capital adequacy requirements associated with the decline in the Japanese stock markets resulted in a decline in commercial lending by Japanese banks in the US (Peek and Rosengren, 1997). The effects on US borrowers and financial flows more broadly are not known, however, and borrowers may have been able to off-set decline in financing.
} 
the conduct of monetary policy or soundness of the financial system (of course, foreign entrants are screened for "fitness and properness"). At the opposite, in many countries, especially developing countries, foreign banks have proven to be a source of stable funding in the face of adverse shocks. $^{21}$ In Argentina especially (where 22\% of all bank assets are held by foreign banks) but also in Mexico in late 1994 and early 1995 the (then few) foreign banks were able to maintain access to off-shore funding while domestic banks experienced strains.

Foreign banks have also played an important role in allowing banking systems to recover from crises. In Mexico and Venezuela foreign banks are emerging as key players in efforts to recapitalize and restructure banks (two troubled banks have been bought up by Spanish banks, a Canadian bank now controls a third bank, and foreign financial institutions are reportedly considering the purchase of several other troubled or intervened banks). In Poland and Hungary foreign banks have brought in very useful know-how and capital, and in New Zealand much new capital. Finally, in several small economies (e.g., Panama) foreign banks play a predominant role in the provision of domestic banking services.

Even though internationalization in the presence of a poorer functioning regulatory and supervisory domestic system may not allow the country to reap all the benefits and could lead to some risks, this needs to be balanced by the fact that foreign FSPs are likely better capitalized and also subject to more stringent supervisory systems (see further Gavin and Hausmann, 1996). This suggests that internationalization need not be limited by the quality of the domestic regulatory and supervisory system, rather the opposite may be the case. In fact, some least developed, lower-income countries have committed themselves under the FSA to (almost) fully open their financial systems to foreign FSPs, suggesting that a poorly-developed financial system and a weak institutional framework need not be constraints to opening up.

It is of course correct that countries stand to benefit more from domestic deregulation (and internationalization) when their financial system satisfies certain minimum regulatory and supervisory requirements. Many of these requirements had already been identified in the literature on domestic deregulation and have been recently further refined (e.g., IMF 1997, BIS 1997, and G-10 1997). These minimum standards cover prudential regulations, and a certain level of institutional development, independence and level of human skills of the regulators. It is also clear that, while national treatment of FSPs does not necessarily guarantee fair international competition, countries should not wait for harmonization to open up, ${ }^{22}$ also since full

\footnotetext{
${ }^{21}$ The G-10 (1997, Annex 1) report has then also included the share of foreign participation in total assets in its illustrative list of indicators of robust financial systems.

${ }^{22}$ Four reasons are typically mentioned (see also William White, 1996a, and Dermine, 1996): first, significant progress in harmonization has already been achieved, particularly through the BIS (for example, Basle capital adequacy requirements), but also through the work of IOSCO and others (see William White 1996a for a review). Second, the net differences in regulatory burden are not that large between many, albeit mostly developed, countries. Furthermore, with open capital accounts, market participants already engage in actions across regulatory jurisdictions which reduce unnecessary regulatory burdens. Thirdly, competition among regulatory systems can lead to an overall reduction in unnecessary regulatory burdens while fears of a race to the bottom are tempered because there are some automatic checks and balances. A race to the top is more likely, as on one hand there will be Footnote continued
} 
harmonization can take considerable time. ${ }^{23}$ The EU Single Market Programme (SMP), for example, has proceeded in a beneficial way without full harmonization among EU-members.

While full harmonization may not be necessary, increased harmonization, including through regional agreements, can of course be beneficial. Many efforts are indeed underway (under the auspices of BIS, G-10, IOSCO, etc.) and these efforts have accelerated recently (William White, 1996a). Complementary, cooperation between various regulatory agencies on the supervision of FSPs and more sharing of information on their cross-border transactions has also increased, and many bilateral and multilateral efforts are underway. Furthermore, the process of internationalization accelerates pressures for improving regulatory systems in many countries. Host countries, for example, may only allow access to their markets if they are sufficiently assured that the regulatory authorities in home countries appropriately supervise their domestic FSPs (for example, the establishment of branches of banks from some emerging markets in the US is being delayed by concerns of US regulators over the quality of supervision of banks in their respective host countries, thus creating additional pressures for further upgrading of host country supervision) ${ }^{24}$

Experiences in a number of countries which have been opened up suggest that local FSPs have not been eliminated-and the quality of the financial system and financial services has improved. Nevertheless, internationalization can put pressure on local FSPs (including foreign FSPs already established). This can lead to constituencies opposing further opening up. Experience and empirical analysis suggests a number of particular circumstances which influence how well domestic FSPs fare after exposure to international competition. As expected, the degree of (prior) domestic regulation has a negative impact on how domestic FSPs fare. ${ }^{25}$ The existing asset-quality of banks and other financial institutions has also been a factor. Better capitalized domestic banks have been able to maintain profitability more easily (Claessens, Demirguc-Kunt, and Huizinga, 1997), suggesting that the existing incentive framework for banks is an important determinant of the adjustment process when opening up. ${ }^{26}$ The scope for new business opportunities (through both old and new services), which in turn is a function of the overall economic growth, has allowed domestic FSPs in countries which opened up to maintain profitability (Claessens, Demirguc-Kunt, and Huizinga, 1997). Possible adverse effects on domestic labor in the financial sector are sometimes mentioned. But the demand for trained

competition between regulatory agencies to attract financial services business while on the other hand the FSPs will have incentives to do business in strong regulatory jurisdictions (with no undue regulatory burden). Fourth, trying to achieve a harmonized set of standards may increase the chances of regulatory capture and poor regulations.

${ }^{23}$ Skipper (1996) describes the OECD harmonization experience for trade in insurance, which started in 1961 and which have essentially been abandoned as no agreement could be reached.

${ }^{24}$ An example is the requirement under NAFTA and the legislation in the US that required Mexican authorities to be capable of undertaking consolidated supervision before Mexican banks could gain greater access to the US market.

${ }^{25}$ At the same time, remaining macroeconomic domestic distortions, including inflation and high real interest rates, while clearly not beneficial from an overall economic point of view, has allowed domestic FSPs to maintain margins (see Claessens, Demirguc-Kunt and Huizinga, 1997).

${ }^{26}$ Banks in lower-income countries appear to have fared worse when foreign banks entered, further indicating that initial institutional development matters. 
labor typically increases as foreign financial firms establish a domestic presence. And in any case, the effects are no different from other sectors experiencing efficiency gains.

Furthermore, some countries which have suffered from severe financial crises-triggered in part by macro and micro distortions - have opened up to foreign FSPs and greatly benefited, thus suggesting that initial conditions can truly be "sunk" costs and need not restrain the opening up. Finally, market concentration, of both foreign banks as well as domestic banks, has a significant positive effect on domestic bank profitability, indicating that market structure and the contestability of the financial sector more generally needs to be taken into account when evaluating the impact of internationalization.

\section{INITIAL CONDITIONS AND COST OF FINANCIAL SERVICES IN ASIA}

\section{INITIAL CONDITIONS}

Strengths Countries in Asia are in a good position for internationalization as many of them have strong fundamentals, also in the financial sector. Most Asian countries have kept real deposit interest rates positive and have deep financial systems, with the ratio of credit to GDP above $50 \%$ and for Hong Kong even up to $285 \%$. They also have gradually liberalized their capital account and have had ample access to foreign financing in recent years. Countries have also announced plans aimed at further deregulating their financial systems, e.g., India, South Korea and Japan. Some Asian countries have already created special, off-shore centers with certain regulatory and tax advantages, which already suggests a desire to allow more internationalization. Several Asian countries have also stated their aim to make their country a regional financial center, which must be based on a belief that their financial institutions can compete on a regional (or global) basis.

High economic growth in Asia creates many new business and financial opportunities which can cushion any negative impact of opening up on existing FSPs. It is, for example, generally projected that financial services will grow at rates much exceeding overall economic growth, with consumer financial services in particular expected to expand at growth rates two to three times GDP growth rates. It also appears that most of Asia, with the possible exception of the transition economies, satisfies the minimum standards in financial system supervision to the same degree as or better than other developing countries do. ${ }^{27}$

Weaknesses At the same time, it is clear, however, that Asian countries have financial systems which are, relative to income levels, institutionally not that well developed (Claessens and Glaessner, 1997, who focus on East Asia, but many of the arguments apply to India too). Many countries in the region, for example, need improvements in their payments systems and the development of money markets and central bank open market operations has lagged in many

\footnotetext{
${ }^{27}$ While regulators in most Asian countries would posses the capacity to regulate their financial systems adequately, not all may have the legal and political backing to exercise their judgments.
} 
countries. Recent global advances in credit analysis and risk management techniques in banks have not been incorporated in banking practices in many Asian countries (many banks, for example, do not appear to measure and manage their currency and interest rates risks very carefully). There is a general scarcity in the region of people with qualified financial skills. And the region's financial system is burdened with relatively large amounts of non-performing loans, resulting in part from poor credit analysis skills.

This slower institutional progress reflects to some extent that institutional development typically lags real sector development and change, with the latter very rapid in East Asia in particular. It also, however, has been due to large state-ownership and poor incentives in many countries, and the heavy role of the government in the financial sector. To date, for example, almost always bank depositors, and often bank owners and managers as well, have not been asked to bear the burden of past mistakes leading to bank insolvencies and failures. In general, countries in the region need to work more on designing and implementing regulatory and supervisory frameworks aimed at creating more robust financial systems. But, these weaknesses need not present barriers to the (further) internationalization of financial services in Asia. At the opposite, foreign FSPs are likely to help in the inevitable transition process. In Thailand, for example, foreign investors and foreign banks may play an important role in the restructuring of weak banks and finance companies, including through the infusion of new capital.

\section{COST OF FINANCIAL SERVICES IN ASIA}

An analysis of the impact of internationalization will have to start with a comparison of the existing costs of and efficiency in providing financial services. In principle, cost estimates for a standardized set of financial services, across all Asian countries could be collected. This approach could follow that of the study of the EU-1992-program (Price Waterhouse, 1988), or that for the recent ex-post 1992, EU study (1997). ${ }^{28}$ The costs and performance measures could then be linked to the degree of de-facto openness.

The problem with a cross-country comparison of cost estimates is that there are a number of regulatory, tax and macro- and micro-economic factors that affect the costs of financial intermediation. In particular, simple comparisons of nominal and real interest rates across countries can be seriously flawed as a means to establish the competitiveness of banking

\footnotetext{
${ }^{28}$ In the first study, cost measures for a number of financial services (all standardized in some fashion, e.g., using share of GDP per capita as a way to standardize loan amounts) were obtained. The exact financial services covered were: banking ( 7 measures: spreads for: consumer loan, credit card, mortgage, and commercial loan to a small and medium-size enterprise; and costs of: LC, FX-draft and traveler cheque); insurance (5 measures: life, home, motor, fire/theft and public liability cover); and securities (4 measures: commission costs for: a private equity transaction, private bond transaction, institutional equity transaction and institutional bond transaction). In the 1997 banking sector study, data on bank performance, costs and economies of scale, interest rates on lending and deposits, mergers and acquisitions activities, cross-border joint-ventures, intra-EU trade in banking services, and banking concentration as well as qualitative responses from questionnaires and individual cases studies (on strategic issues) were used to study the effect of the Single Market Programme across countries and institutions.
} 
systems. Box 3 provides an example for Argentina of some of the corrections which need to be made to allow for better estimates of the cost of financial intermediation using aggregate financial data. The decomposition shows that most of the level of the nominal interest rate can be explained by factors other than the efficiency of financial intermediation.

Measuring directly financial intermediation costs on a comparable basis across countries can thus be difficult as there are many factors which affect the costs in providing financial services in a particular country. Banking margins, for example, are affected by reserve requirements (which raise the intermediation costs), inflation (which influence the degree of profitability necessary to maintain real capital), various aspects of taxation of financial services, (large) credit-differentials between (firms in) countries, the effects of non-performing loans, and the presence of a deposit insurance scheme. To illustrate this complexity, we decomposed the raw, aggregate banking spread for seven East Asian countries using an accounting model (Montes-Negret and Papi, 1996) to get at a cost of financial intermediation which corrected aggregate margins for reserve requirements, inflation (to maintain real bank capital), some aspects of taxation, the required rate of return on bank capital and the effects of non-performing loans. Table 2 provides the figures (with substantial methodological and data problems remaining, for example, the (net) regulatory burden on the financial sector is very hard to compute). ${ }^{29}$ The large differences between the actual reported margins and the derived intermediation costs (net of corrections) make clear that the corrections are large. But, the table makes the point that raw banking spreads can be a very misleading measure of intermediation costs.

\footnotetext{
${ }^{29}$ The importance of taxation on costs of financial services, for example, depends on the ability of the financial institutions to pass this tax on to their consumers (Demirguc-Kunt and Huizinga, 1997, find that banks are able to pass-through income taxes to consumers).
} 
Box 3: Decomposing the Level of Nominal Interest Rates

Box Table 1 provides a decomposition of the domestic lending interest rates to non-prime borrowers for Argentina. The domestic interest rate is decomposed into the international rates (US dollar or other relevant currency); country risk premium; expected nominal exchange rate depreciation (or appreciation) (or separately, real exchange rate depreciation (or appreciation) and expected inflation differential); exchange rate risk premium; direct and indirect taxes on financial services; credit risks of domestic banks; bank profit margins; and credit spreads.

Box Table 1: Decomposition of Lending Rate: Argentina

\begin{tabular}{|c|c|c|}
\hline & April 1996 & April 1997 \\
\hline \multicolumn{3}{|l|}{ Macroeconomic Risks } \\
\hline Base Rate - US Treasury Bills ( 3 months) & 4.96 & 5.10 \\
\hline Country Risk & 0.76 & 0.35 \\
\hline Argentina's Treasury Bills in dollars ( 3 months) & 5.72 & 5.45 \\
\hline Exchange Rate Risk on Government Debt & 1.20 & 0.15 \\
\hline Argentina's Treasury Bills in pesos ( 3 months) & 6.92 & 5.60 \\
\hline \multicolumn{3}{|l|}{ Micro-economic Risks } \\
\hline CD in dollars ( 3 months) & 7.83 & 5.79 \\
\hline Exchange Rate Risk on Bank's Deposits & 2.87 & 0.98 \\
\hline Risk of Banks & 1.20 & 0.15 \\
\hline $\mathrm{CD}$ in pesos ( 3 months) & 11.90 & 6.92 \\
\hline Average (Peso + Dollar) Deposit Rate & 9.46 & 6.31 \\
\hline Operational Costs & 7.10 & 5.33 \\
\hline Pure Costs & 3.91 & 3.20 \\
\hline Greater Rotation of Deposits (-E-) & 3.20 & 2.13 \\
\hline Reserves for non-performing loans & 2.43 & 1.48 \\
\hline Taxes & 1.80 & 0.97 \\
\hline (-) Income on Services & -2.70 & -2.91 \\
\hline Profits & 2.35 & 2.79 \\
\hline Average Lending Rate (Pesos + Dollars) & 20.40 & 13.98 \\
\hline
\end{tabular}

Note: Argentina runs a currency board with the peso to the US-dollar rate set at one.

Source: Arriazu (1997).

In general, many other factors will affect margins (see also Vittas, 1991). The EU-study (1997) for example, found that margins were significantly influenced by business cycle effects and the increased emphasis on strengthening capital adequacy and shareholder value during the last few years, which meant a need for higher profitability. In addition, structural changes in financial systems will affect changes in the cost of financial intermediation. Over the last few years, for example, many Asian countries have made significant improvements in the institutional infrastructure for equity markets. Trading and settlement systems have improved, regulatory frameworks have been clarified, etc., thus reducing the cost of financial intermediation through equity markets. While some of these effects are not independent of the opening up to foreign capital and financial intermediation (the improvement in capital markets infrastructure, 
for example, has been to a significant extent driven by foreign forces, see further World Bank 1997), these effects are difficult to correct for.

The approach taken here is to document several measures of costs of financial intermediation, including average costs as reported from individual bank balance sheets and profits and loss statements, estimates of the efficiency of doing an equity transaction by an institutional investor in the respective markets (from institutional investors surveys), and operational costs and pay-back measures for insurance (Tables 3 through 5). We then try to relate these to measures of openness.

\section{STRUCTURE AND INSTITUTIONAL QUALITY OF FINANCIAL SERVICES PROVISION IN ASIA}

The structure of the financial sector and its various subsectors matters in a number of respects for the costs and efficiency of financial services. First, as for any economic activity, the degree of competition can be influenced by the number and type of participants, both on the user and provider side of financial services. Demirguc-Kunt and Huizinga (1997) find, for example, that market concentration has a positive effect on bank profitability. Second, the way financial intermediaries are allowed to organize (and organize themselves in practice) can importantly influence whether possible economies of scope and scale in the joint production of various financial services can be realized (see for example, Saunders and Walter, 1994, which promote the case for universal banking in part on economics of scale and scope; see further Berger and Humphrey 1996, and Barth, Nolle and Rice, 1997). Third, there are broader links between the various parts of the financial sector as well as the real sector which can influence the costs of financial intermediation. Demirguc-Kunt and Huizinga (1997) find, for example, that the development of the stock market affects net interest margins positively, suggesting a complementarity between bank and equity financing. Fourth, the quality of the institutional framework will greatly influence the efficiency with which financial institutions are willing or able to operate.

In principle, detailed empirical work may allow one to separate the effects of (lack of) internationalization from other structural characteristics (which may or may not be related to policies) affecting costs end efficiency. We acknowledge this but at the same time realize that this is a new research area even for developed countries (see Berger and Humphrey, 1996 and Berger et al, 1993 for an overview). We rather present a simple overview of the structure of the financial system in each country, all as of the end of 1996 (Table 6), where the information is collected from World Bank and IMF, central banks and private markets reports in and outside the Asian countries.

About half of the Asian countries (India, Malaysia, the Philippines, Singapore and Thailand) allow (with some restrictions) the underwriting, stock-broking, and fund management by commercial banks. In Hong Kong only merchant banks are allowed to engage in securities underwriting and trading; in Indonesia and South Korea only securities firms are allowed to engage in these businesses. In all countries except Indonesia and South Korea, banks are allowed 
to have equity stakes in non-financial and financial institutions, up to certain percentages (varying from $15 \%$ to $40 \%$ ) of banks' equity. Indonesia does allow investments by banks in securities companies, up to $15 \%$ of the banks or the securities company's equity.

Table 7 provides the number of banks and branches, market concentration (share of top banks) and the number of domestic and foreign insurance companies. Indonesia has the largest absolute number of banks (domestic and foreign combined), more than 200. The least number of banks are in Thailand. India has the largest number of branches and Singapore the least. But, relative to population, Indonesia has the least number of bank branches (about 20 per million people) and Hong Kong the most (more than 200 per million people). Hong Kong has the largest number of foreign banks, more than 150 (which is actually more than the US), with Malaysia, the Philippines and Thailand about 15, and South Korea the least, 9. Singapore has the most concentrated banking system in the region, with the top three banks having about a 3/4 share of the total loan market. In Hong Kong, Malaysia, and Thailand, the top three banks have about half of the loan market, while in the other markets the top three banks have $1 / 3$ or less of the market. State banks are most important in India, followed by Indonesia and least important in Thailand, Malaysia and Hong Kong. For insurance, the numbers of domestic companies are substantial for all countries except India, but foreign insurance firms are few-except for Singapore, and in India and Indonesia there are actually no foreign insurers present.

Table 8 provides the financial depth (ratio of credit provided by the banking system to GDP); stock and bond market capitalization (as a ratio to GDP), and liquidity of these markets (turnover as a share of market capitalization). Hong Kong and Singapore stand out as having very deep and broad financial systems. South Korea, Malaysia and Thailand have reasonable deep financial system, while those of the Philippines and Indonesia are less deep, and that of India is the least deep.

Table 9 provides information on the institutional environment for banking and quality of loan portfolios. An indicator of quality of the operating and regulatory environment for banks (deposit insurance, regulatory integrity, quality of supervisory agencies, and legal framework) for Asian countries has been provided by Ramos (1997a). He ranks bank supervision quality from very good and improving for Hong Kong to weak for Thailand. He also classifies the degree of transparency and the quality of disclosure. Here the rating is from very good for Hong Kong to poor for Singapore. Ramos (1997b) provides an indicator of the overall fragility of Asian systems, FRAGILITY. Here he ranks as Hong Kong and Singapore as most solid, and Thailand as the most fragile. His CAMELOT indicator (Capital, Assets, Management, Earnings, Liquidity, Operating environment, and Transparency) for domestic banks' quality varies similarly, from Hong Kong as the best, India as the worst, and Thailand as the next to worst (South Korea is not reported). Table 9 also reports data on non-performing loans, both from official sources and as estimated recently by Ramos (1997b). The accuracy of the data from official sources in reporting the true degree of non-performing assets can be limited-as recent events in Thailand have made clear-and as the much higher figure estimated by Ramos (1997b) for both Thailand and Indonesia compared to the officially reported figures suggest. Nevertheless, the banking systems 
of India, Indonesia and Thailand stand out as having a high degree of reported non-performing loans as of end-1996, 19.5\%,10.4\% and $7.7 \%$ respectively.

\section{BARRIERS TO FREE FLOW OF FINANCIAL SERVICES IN ASIA}

An analysis of barriers to the free flows of financial services will have to start with the current formal and practical barriers in place by type of financial services. These barriers can be further separated into entry (or market access) and lack of national treatment barriers, and limits on the cross-border provision of financial services. ${ }^{30}$ Table 10 summarizes the degree of entry barriers as of the end of 1996, where we use an indicator of 1 through 5, with 1 being most closed and 5 most open. The indicator weighs the various type of barriers (right of establishment and ownership, limits on business activity (ability to establishes branch offices and ATMs, restrictions on lending, universal banking authority), and residency requirements). ${ }^{31}$ The table is based on a number of sources and has as much as possible been cross-checked with country officials and other sources (including private markets in and outside country). The table provides both current barriers as well as the degree to which countries have already committed themselves to opening up. Annex Table 1 provides the criteria used to create the ratings (details on barriers for individual countries are available from the authors).

There is a large diversity in current entry barriers across the countries and sectors within the countries, varying from almost completely open (Hong Kong, for all financial services) to virtually closed (South Korea, particularly for banking services and India for insurance services). In some cases, restrictions apply equally to domestic and foreign FSPs. Malaysia, for example, while it has more barriers for foreigners, has not licensed any new domestic or foreign securities brokers or insurance companies in the last few years. And South Korea imposes very high capital requirements on all investment management firms. But, there are quite a number of restrictions which apply to foreign FSPs only. In many Asian countries, the ability of foreign banks to establish branches is much more limited than that of domestic banks and in all countries foreign banks face limits and tighter regulations in opening up ATMs.

Across the countries, entry into banking services tends to be slightly more liberal than for insurance or securities markets, although there are significant differences across countries in the treatment of the three type of financial services. For securities markets, the index shows Hong Kong as the most open and Thailand as the least open, with South Korea and India also very

\footnotetext{
${ }^{30}$ In the format followed under the GATS-negotiations, four modes of opening up are distinguished: commercial presence (i.e., entry of foreign FSP, through new establishment, joint ventures, or acquisition of existing firms, including through privatizations); cross-border supply; movement of consumers; or movement of suppliers. For internationalization of financial services, commercial presence and cross-border supply are in practice the most important.

${ }^{31}$ All countries make entry dependent on the foreign FSP satisfying certain prudential guidelines. In some countries, entry is in addition explicitly limited to the world's top 200 (or some other number) of FSPs. We do not consider these conditions in principle to constitute barriers to entry, although if their implementation is, we would have tried to capture it.
} 
closed. For insurance markets, the practice index shows that Hong Kong and Singapore are the least restrictive, followed by Thailand, Philippines, Indonesia and South Korea, and then Malaysia, with India as essentially closed. Restrictions on cross-border trade are somewhat less than entry restrictions, with several countries allowing in principle free access to off-shore banking services. India is an exception as it has significant capital controls. Nevertheless, barriers against free trade in financial services are highly correlated with entry barriers; most of Asia, for example, does not allow cross-border trade in insurance services.

Countries have already made commitments regarding the degree of financial services liberalization under the Financial Services Agreement (FSA) of the GATS, 1995 (details on these countries' commitments $^{32}$ (or "schedules") as per the end of the negotiations in mid-1995 are available from the authors). Table 10 summarizes these in the indicator "Commitments" which again ranges from 1 (most closed) to 5 (most open). Based on 1995 commitments, the most open banking market would be Hong Kong, followed by Indonesia, Thailand, the Philippines, India, Malaysia, Singapore and South Korea. Committed to the most open securities market is Hong Kong, followed by Indonesia, Singapore, India, Malaysia, the Philippines, Thailand and South Korea. The country committed to opening up its insurance sector the most is Hong Kong, followed by Singapore, Indonesia, Philippines, Thailand, Malaysia, South Korea and India.

Comparing the commitment and practice indicator (and more detailed analysis available from the authors) shows that commitments can fall short of current practices as well as go beyond them. Hong Kong, for example, is committed to more liberal entry in insurance services than current practices. Many Asia countries, however, have made commitments which fall short of current practices, particularly in banking services, but also in other financial services. The Philippines, for example, has committed to allowing ownership in banking only up to $49 \%$ while current practice limits it to up to $60 \%$ for existing banks and $100 \%$ for new banks. And Indonesia did not bind to its current practice of allowing up to $80 \%$ ownership in joint ventures in brokerage services, but, as most other Asian countries, only committed to allowing ownership in financial services up to $49 \%$. Compared to other countries, commitments also fall short of the actual state of openness. While the share of assets held by foreign banks in Asia is below that of many other countries, for example, the level of commitment in the 1995 agreement was relatively even lower that of many other countries (see Sorsa, 1997).

In addition to current barriers and commitments under the FSA, the analysis will also have to take into account the history and likely progression in these barriers. Several Asian governments have recently announced unilateral measures which go beyond the current schedules. Singapore (in part motivated by a desire to further expand itself as a regional financial center), Japan (as part of the Big Bang), and South Korea (in the context of the accession to the OECD), for example, have announced liberalization of their financial systems, including greater access by foreign FSPs recently. Offers submitted under the current round also

\footnotetext{
${ }^{32}$ Since this was an interim agreement, countries reserved the right to change them during the currently ongoing negotiations. We do not analyze already submitted offers for the current negotiations as not all Asian countries have made offers.
} 
tend to go beyond the previous offers. In addition, countries have made some commitments under regional agreements (ASEAN and APEC). It is possible that some of this future opening up has been anticipated and led to changes in the current domestic financial industry and could thus be captured under current practice. ${ }^{33}$

Table 10 also provides an indicator for the severity of capital controls and exchange rate restrictions, both inward and outward. ${ }^{34}$ The indicator shows that there is quite a variety among Asian countries in the severity of their capital controls: Hong Kong is almost completely open (except for some restrictions on inward investment), Indonesia has been very open-since 1970, South Korea still had significant controls until recently, and India is the most closed. Most of the capital controls, such as remittance restrictions, apply to all type of firms and investors, but many can be expected to affect FSPs more severely. In addition, there exist limits on foreign portfolio and direct investment-varying substantially among Asian countries ${ }^{35}$-that can affect the attractiveness to foreign FSPs of entering certain markets.

In addition to these barriers, there are other, legal barriers, some of which are financial sector-specific and others which apply more generally (the latter would include, for example, general labor restrictions limiting the hiring of foreign professionals, etc.). Financial market and regulatory practices can also constitute barriers against foreign service providers (e.g., preferential access to central bank financing) and foreign FSPs may face some "nuisance" barriers. Furthermore, financial intermediation depends on a host of auxiliary services (accounting, legal, consulting), many of which are not fully liberalized in Asian countries (accounting services in Indonesia, for example, have nationality limits) and which can make it more difficult for foreign FSPs to provide financial services in an efficient manner.

It is impossible to quantify all these factors, let alone to assert whether or not they constitute effective (binding) barriers to the establishment of foreign firms. Even low formal or other barriers may not be binding as some markets may not be attractive to foreign FSPs. It could also be the case that some of these barriers constitute one of the reasons for foreign FSPs to establish themselves in these markets as they have a comparative advantage in overcoming these hurdles or benefiting from resulting "inefficiencies" (and, relatedly, the current costs of providing financial services may have a positive relationship with foreign FSP-presence as it increases the attractiveness of the entering). Analyzing the exact importance of all these effects is beyond the scope of this study. But, it appears that in most countries barriers are binding. For the eight

${ }^{33}$ There is evidence for the US and EU that deregulation has had anticipatory effects (see EU 1997 and Berger and Humphrey, 1996). The removal of interstate branching requirements in the US has been anticipated and led to a consolidation of the banking industry.

${ }^{34}$ It is derived as the weighted average of six restrictions (inward remittances, foreign borrowing, lending to nonresidents, investment abroad, investment into the country, and foreign exchange allowance) as reported in the latest IMF's Annual Yearbook on Exchange Rate Arrangements and Restrictions. The index is again from 1 (most closed) to 5 (most open).

${ }^{35}$ For equity investments, for example, individual approval is required in case of Malaysia (for amounts over M\$ 5 million), ownership limits up to 25 percent exist for South Korea, and up to 49 percent for Indonesia (the restriction in Indonesia has been recently been lifted). No restrictions exist in case of Hong Kong and for many sectors in the Philippines. See further Securities Industry Association, 1997. 
Asian countries, for example, the correlations between the openness indicator here and the number of foreign banks (relative to the total number of banks in the particular country) and the share of total bank assets held by majority-owned banks at the end of 1995 (as reported by Claessens et al, 1997) are 0.86 and 0.54 respectively. And for insurance, the correlation between the openness indicator for insurance and the share of life-insurance premium volume collected by foreign-owned institutions is 0.86 . In any case, these barriers are at least a cost, as they presumably would otherwise not so often be mentioned by foreign financial firms.

\section{MAPPING MEASURES OF OPENNESS TO MEASURES OF COSTS OF FINANCIAL SERVICES.}

As will be clear by now, any attempt to link the costs of financial services with barriers to foreign FSPs, even by detailed types of financial service or sub-sector, will have to be very tentative given the many other factors involved. One approach is to use data on individual FSPs (with of course data adjusted to international comparable measures) to investigate margins (by type of activity), operating and other costs, and profits. This is done by Claessens, DemirgucKunt, and Huizinga, 1997 for a large number (80) of countries. Separating domestically-owned from foreign-owned banks, they find that an increase in the share of foreign banks leads to lower profitability and overhead expenses for domestic banks. ${ }^{36}$ We use the same measures here for our set of Asian countries.

Alternatively, individual firm (borrowers and issuers) data can be used to relate the effects of internationalization on the access firms have and costs they pay for various financial services, as well as improvements in the allocation of resources as a result of a better financial system and better corporate governance. These type of studies have been done in the context of domestic financial deregulation. Harris, Schianterelli, and Siregar, 1994, for example, study the effect that deregulation in Indonesia has had on the access of firms to bank financing. They find that deregulation broadened the class of firms which had access to bank financing and lowered their costs. Similar studies could be done regarding the effect of foreign entry.

\footnotetext{
${ }^{36}$ They also find that foreign banks achieve higher profits in developing countries than domestic banks and lower profit in developed countries than domestic banks. The first finding suggests that foreign banks have comparative advantage in these markets. One interpretation of the second finding is that the foreign banks are too eager to establish market share in developed countries and may therefore have lower profits. There is supporting empirical evidence for the US which shows that foreign banks are actually less efficient than domestic banks (Deyoung and Nolle, 1996). These tests can be expanded to include tests regarding the contestability of the industry, which would require developing measures of efficiency which adjust for relevant economies of scope and scale (using methodologies typically used in studies of the developed countries' financial systems, see Berger et al. 1993 and Berger and Humphrey, 1996 for reviews; Shaffer 1990 provides for an application of a non-structural test to Canada and Molyneux, Lloyd-Williams and Thornton, 1994, to European banking). Furthermore, state-owned banks could be distinguished from private banks to see whether there are significant differences in efficiency.
} 
In addition, one can study the effects of (lack of) internationalization on the breadth and quality of financial services. While it is conceptually clear that one can expect better financial services from internationalization, so far this has, at best, only been documented anecdotally and a systematic review would be useful. In addition, it would be useful to document improvements in the institutional development of the financial sector, including supervision, and regulation. So far, lack of cross-country institutional development indicators on supervision and regulation makes this difficult (for work on Asia, see Ramos 1997a, and for Latin America, see Pearly, 1997). There is some indirect evidence, however, that the presence of foreign investors leads to an improvement in the overall institutional development of capital markets (see chapter 6, World Bank, 1997b).

Given the absence of this type of detailed information and ability to perform these tests and comparisons for a large number of Asia countries, we employ a number of simpler tests and comparisons. Specifically, we use our indicators reported in section 5, Tables $3-5$. We plot these measures against our quantitative measure of the barriers to foreign FSPs. Since we distinguish between the three services (banking, insurance and securities), we discuss the various costs and efficiency measures and barrier indexes separately.

Banking Services Provision We use 1995 net margins, operating costs (overhead, including personnel costs) and before tax profitability (the figures are averages of individual domestic banks' reported balance sheets and profit and loss statements). Figure 1 indicates that there exist a negative relationship between net margins and the share of foreign banks (in numbers). ${ }^{37}$ The Philippines has the highest net margin and little foreign bank presence (in terms of number of banks). Hong Kong and Singapore are countries in the lower-right hand quadrant, i.e., they score high on foreign bank presence and low on net margins and overhead. Net margins and overhead also have a negative correlation with the openness indicator for banking services. Interesting, profit figures show a positive relationship with foreign bank presence, consistent with the findings of Claessens et al. 1997. This may reflect that foreign banks are attracted to markets with high profitability. It may also be the congruence of countries pursuing domestic deregulation which, in the short-run at least, is often associated with an increased emphasis on profitability due to more emphasis on profitability by owners and on increased capital adequacy by supervisors. Finally, it may reflect the positive influence of foreign banks in terms of encouraging domestic banks to pursue greater share-holder value.

The fact that more foreign bank presence goes together with greater profitability and lower net margins could be that where there are more foreign banks competition increases in deposit taking and lending, thus reducing margins, but forcing domestic (as well as foreign banks) to develop their fee-based (e.g., non-margin) business. Thus where there are more foreign banks, the incentives to diversify and provide a wider range of non-interest related products and services increase. In addition, as greater presence of foreign banks is associated with lower overhead costs, profits are boosted.

\footnotetext{
${ }^{37}$ Foreign banks are those banks in which foreigners have at least a $50 \%$ ownership share. It includes subsidiaries as well as joint-ventures.
} 
Figure 2 repeats the same analysis, except here we use the share of assets held by foreign banks in total assets. Note that these are the shares of foreign banks among those banks which report balance sheet and profitability and loss-statements. As a result, the shares very likely overstate the importance of foreign banks as foreign banks are more likely to provide complete statements. ${ }^{38}$ For Singapore, for example, the share of reported foreign banks assets is almost $80 \%$, a significant overstatement in terms of local financial intermediation activity. ${ }^{39}$ Nevertheless, the figures confirm the earlier result: a negative relationship between net margins and overhead and foreign banks' presence and a positive relationship between foreign banks' presence and profitability.

As noted, other country experiences suggest that there is likely a relationship between the degree of openness and the institutional quality and fragility of the financial sector. Figure 3 plots therefore the CAMELOT-score for the banking systems of Table 9 (with higher scores indicating a less transparent and institutionally less developed system) against the share of foreign banks (in numbers) as well as against the degree of openness (as measured by the practice indicator of Table 10). The CAMELOT-indicator is negatively associated with both the relative presence of foreign banks and the degree of openness, i.e., the institutional quality improves as countries become more open to foreign competition. ${ }^{40}$ Figure 3 also plots the FRAGILITY score of Table 9 against the same two openness indicators. There also appears to be a negative relationship between FRAGILITY and the openness: the more open financial systems have a lower FRAGILITY score. ${ }^{41}$ Openness appears thus to be associated with improved institutional development and greater robustness of banking systems in Asia.

Securities Markets We first plot efficiency measures for the securities industry to the openness indexes. The efficiency measures for the comparisons were taken from data from Global Securities Consulting Services (GSCS) and refer to 1995 . We took two efficiency measures: settlement and operational benchmarks. The former measures the efficiency of the securities markets in fulfilling confirmed obligations; the indicator takes into account the average trade size, local market interest rates, the share of failed trades and the length of time for which trades failed. The latter measure is an indicator of the securities industry's efficiency in settlement and safekeeping; the index incorporates operational factors such as compliance with G30 recommendations, effectiveness of the legal and regulator majeure frameworks, counterparty and force risks. Figure 4 shows a positive relationship between settlement and operational efficiency and openness (as measured by the practice indicator of Table 10). Hong Kong has a very efficient trading system and relatively most open market, and India has the least efficient and one of the most closed markets. For Indonesia and the Philippines, there is also a positive

\footnotetext{
${ }^{38}$ A systematic overestimation of the presence of foreign banks would of course imply that the regression lines would be steeper.

${ }^{39}$ In Singapore, foreign banks are mainly involved in off-shore business, rather than domestic intermediation.

${ }^{40}$ The correlation coefficients between the CAMELOT-indicator and the ratio of the number of foreign to domestic banks and the openness indicator are -0.67 and -0.44 respectively.

${ }^{41}$ The correlation coefficients between the FRAGILITY-indicator and the ratio of the number of foreign to domestic banks and the openness indicator are -0.53 and -0.38 respectively
} 
relationship between openness and efficiency. For the other four countries, the efficiency of the trading systems differs little and there is no clear relationship with openness.

Figure 5 provides the cumulative rate of return index, the cumulative transaction cost measures, and the relative effect of costs on net rate of return (all from Table 4), plotted against the index of openness of the securities industries. There is clear positive relationship between the rate of return index and openness. And there are negative relationship between the level of transactions and relative transactions costs for these emerging markets. India appears to be an outlier in terms of cumulative absolute costs, while the Philippines is an outlier in terms of relative costs (mainly as the rate of return index showed a poor performance for the Philippines over this period). But, overall these figures suggest that more open securities markets are associated with higher rates of return and lower transaction costs.

Life-Insurance Services Provision We take two cost measures-the pay-back ratio and operating expense ratio for life insurance. The former relates earnings from a life insurance company's investments to income from premiums adjusted for the mismatching periods for revenue and outlay. A low pay-back ratio indicates relative inefficiency while an excessively high figure could suggest a low premium rate undermining the financial viability of insurers. The operating expense ratio shows the percentage of premiums spent for operating expenses. The cost measures for the insurance industry are obtained from the national supervisory authorities and the insurance associations in each country. These measures are standardized for definitions and classification of data as well as calculation methods across countries. Data for Hong Kong are not available.

We plot the insurance markets' openness index (current practice) and both cost measures for the six countries for which we have data (Figure 6). We find negative relationships between payback and operating costs and openness. In terms of operating costs, South Korea appears as an outlier, in the sense that South Korea's insurance sector is relatively closed, but has low costs efficient. Life-insurance firms from Malaysia and Thailand appear to have relative high operating costs. The data we have on performance of insurance companies are weak, however. In South Korea, for example, many insurance companies are reportedly technically insolvent, so the low operating costs for firms in Korea could be a very misleading indicator of their true performance. 


\section{CONCLUSIONS AND POLICY IMPLICATIONS}

The paper discusses the links between three important reforms: internationalization of financial services, domestic financial deregulation, and capital account liberalization. Internationalization relates to the degree of capital account liberalization as it determines the potential gains and benefits from access to foreign financial services provided domestically relative to access provided and obtained off-shore. Internationalization also relates to domestic financial deregulation as it influences the quality and competitiveness of domestic financial services providers. A review of experiences with internationalization suggests that almost independent of the state of development of the domestic financial system and the openness of the capital account, internationalization can help in the process of building more robust and efficient financial systems by introducing international practices and standards, by improving the quality, efficiency and breadth of financial services, and by allowing more stable sources of funds. Given the state of institutional development of many Asian financial systems, these benefits could be substantial.

Cross-country empirical evidence for Asia specifically suggests that the limited openness to date has been costly in terms of slower institutional development, greater fragility and higher costs of financial services. For banking services in eight Asian countries, the paper finds a clear negative relationship between net margins and de-facto or de-jure openness to foreign FSPs. At the same time, there is a positive relationship between profitability and openness, suggesting that openness encourages banks to reduce costs and diversify their income (by greater reliance on feeincome). The more closed Asian banking systems also appear less institutional developed and more fragile. For securities markets, there is a positive relationship between the degree of openness and measures of functional efficiency. For life-insurance markets, we find negative relationships between pay-back and operating costs and openness. Hong Kong stands out as having both open as well as efficient and robust financial markets for all three type of financial services.

What do these economic and political arguments, lessons from experiences and Asiaspecific evidence imply for further internationalization, financial reform, and capital account liberalization? Asian countries will not benefit to the degree possible from financial services liberalization if their domestic financial system remains heavily restricted by regulations that inhibit foreign entry, and limit domestic competition and the efficient provision of financial services liberalization. This would put the domestic industry at a competitive disadvantage, create distortions, and risks inefficient resource allocation. Extensive capital controls will not allow the various FSPs to explore their comparative advantage and may introduce distortions and risks as domestic and foreign FSPs will try to circumvent them. In general, capital controls are unlikely to reduce outflows and have been found at best to change the composition of inflows, but not the level permanently. In case, controls are deemed necessary, internationalization does not limit the ability of authorities to impose controls or limits on financial institutions for prudential reasons, as long as they are applied even-handed to domestic and foreign financial firms. While in principle internationalization in the presence of a poorly regulated and supervised financial domestic system could create increased risks, this needs to balanced by the fact that foreign FSPs are likely better capitalized and also subject to more stringent supervisory 
systems in their home countries. This suggests that internationalization in Asia need not be limited by the quality of the domestic regulatory and supervisory system. This is confirmed by the fact that several institutionally very poorly developed countries have committed themselves under FSA to fully opening up.

What lessons are there for these countries for the current negotiations on financial services under GATS? Given the significant benefits of internationalization, Asian countries would appear to stand to gain from opening up, either unilateral or multilateral. Countries may, however, face adjustment cost in internationalizing their financial systems, including effects on labor. They might consider committing through the FSA to a phased program of opening up over some agreed time frame (possibly complemented with measures which could smooth the transition to a more open environment). Mexico committed in the context of NAFTA to a phased program of opening up over an agreed time frame, which included progressive market capitalization arrangements which could modulate the growth of foreign participation in the sector in the event of overly rapid foreign penetration. In the NAFTA safeguards were also included in case "adverse" effects were to arise when the share of all commercial bank assets held by foreign-owned banks exceeded certain threshold levels. ${ }^{42} \mathrm{~A}$ commitment would provide greater security for foreign financial firms of the environment under which they will operate and thus could lead to a greater level of foreign participation in the financial sector. It could also reduce the risk premium charged by those foreign institutions which will enter the country, which in turn would lead to costs savings for consumers. And, it would lend credibility to countries' reform approaches, something which is at a premium today. By themselves, these factors would help in overcoming the adjustment costs.

The FSA does not cover activities by central banks and governments in pursuit of monetary policy or exchange rate policy and allows members to take any prudential measures, including for example, the imposition of limits on the access of domestic financial institutions to international financial markets, as long as they are not used as a means to avoiding commitments under the GATS. Furthermore, the WTO-process explicitly includes mechanisms which allow temporary suspension of commitments in the event of pronounced economic imbalances (so called prudential carve-out and balance of payments safeguard provisions). These provisions should already provide the flexibility needed for governments to deal with any adverse consequences and no further safeguards appear necessary.

Countries should try to avoid the use of quantitative restrictions, a well-known inefficient form of regulation, but rather give consideration to converting them into price-based measures (provided that their effect is equivalent in granting de facto national treatment and does not place

\footnotetext{
${ }^{42}$ Specifically, Mexico could request consultations to limit entry and reduce adverse effects. Adverse effects could be associated with threat of control of domestic payments or effects on the independence of Mexican monetary and exchange rate policy. In the end, these safeguards were not used and the foreign banks' share exceeded the original threshold levels in 1996. In general, the merit of including safeguards which are triggered by adverse economic events and conditioned on market shares may have limited value as it will be exactly in time of adverse economic events that foreign banks can be a stabilizing influence and when the country may want to open up its financial sector more.
} 
foreign FSPs at a competitive disadvantage in the host country market). Where relevant, countries should also try to harness the interests of foreign FSPs in entering the country. This can done as part of the process of the restructuring of the domestic financial system. In many countries, foreign banks are assisting in the restructuring and recapitalization of existing institutions. In several transition economies, for example, twinning and other technical assistance arrangements with banks from developed countries is helping improve the level of institutional development of individual financial institutions.

In sum, in the current environment especially, there is a large premium on a credible, consistent financial sector development strategy. The FSA can help countries achieve this credibility, with built-in adequate safeguards. 


\section{References}

Arriazu, Ricardo, 1997, "Open Financial Systems Argentina," paper presented at workshop organized by EDI on "Internationalization of Financial Services," August 8, Singapore.

Barajas, Adolfo, 1996, "Interest Rates, Market Power, and Financial Taxation: An Application to Colombian Banks 1974-1988," mimeo, IMF.

Barfield, Claude E. (ed.), 1996, International financial markets, Washington D.C.: American Enterprise Institute.

Barth, James R., Daniel E. Nolle, and Tara N. Rice, 1997, "Commercial banking structure, regulation, and performance, an international comparison," Comptroller of the Currency Economics Working Paper 97-6.

Bhattacharya, Joydeep, 1993, "The Role of Foreign Banks in Developing Countries: A Survey of the Evidence," Cornell University, mimeo.

Berger, Allen, and David Humphrey, 1996, "Efficiency of Financial Institutions: International Survey and Directions for Future Research," mimeo, May, Board of Governors of the Federal Reserve System.

BIS, 1997, "Core Principles for Effective Banking Supervision," consultative paper issued by the Basle Committee on Banking Supervision, April, Basle.

Borish, Michael S., Wei Ding, and Michel Noël, 1996, "On the road to EU accession: financial sector development in Central Europe," World Bank discussion paper, No: 345.

Caprio, Gerard Jr. and Daniela Klingebiel, 1997, "Bank Insolvency: Bad Luck, Bad Policy or Bad Banking?," in Annual Bank Conference on Development Economics: 1996, edited by Michael Bruno and Boris Pleskovic.

Caprio, Gerard, Jr. and Lawrence H. Summers. 1996, "Financial Reform: Beyond Laissez Faire," in The Stability of the Financial System: Reflections on the 60th Anniversary of the 1933 Banking Crisis, edited by Dimitri Papadimitriou, MacMillan Press.

Claessens, Stijn, 1997 "Estimates of Capital Flight and Its Behavior," Revista de Análisis Ecónomico, 12:1, 3-34.

Claessens, Stijn, and Thomas Glaessner, 1997, "Are Financial Sector Weaknesses Undermining the Asian Miracle?," Directions in Development, September, World Bank

Claessens, Stijn, and Brian Hindley, 1997, "Internationalization of financial services: issues for developing countries," mimeo, World Bank, March. 
Claessens, Stijn, Asli Demirguc-Kunt, and Harry Huizinga, 1997, "How does foreign entry affect the domestic banking market?," mimeo, World Bank, July

Demirguc-Kunt, Asli and Harry Huizinga, 1997, "Determinants of commercial bank interest margins and profitability: international evidence," mimeo, World Bank, July.

Deyoung, Robert and Nolle, Daniel. E., 1996, "Foreign-owned banks in the United States: Earning Market Share or Buying It?," Journal of Money Credit and Banking, 28, 4, Nov Part 1, 622-636.

Dick, Astrid, 1996, "X-Inefficiency in the Private Banking Sector of Argentina: Its Importance with Respect to Economics of Scale and Economies of Joint-Production," mimeo, Banco Central de La Republica Argentina, October.

Dooley, Michael, 1995, "Capital Controls: A Survey of the Literature," NBER Working Paper, No. 5352.

EU/Price Waterhouse, 1988, "Research on the Costs of Non-Europe: Basic Findings," European Economy, Vol. 9, Price Waterhouse.

EU, 1997, The Single Market Review, Volume 11-3, "Credit Institutions and Banking," published for the European Commission by Kogan Page, London, UK. (In mimeo form: "A study of the effectiveness and impact on Internal Market Integration on the banking and credit sector: A Summary Report," by Economic Research Europe Ltd., in collaboration with Public and Corporate Consultants (PACEC) and The Institute of European Finance).

G-10, 1997, "Financial Stability in Emerging Market Economies: A strategy for the formulation, adoption and implementation of sound principles and practices to strengthen financial systems," Report of the working party on financial stability in emerging market economies, April, Basle.

Gardener, E.P.M. and P. Molyneux, 1996, Efficiency in European Banking, John Wiley \& Sons Publishers, Chichester, UK.

Gardener, Edward, Philip Molyneux and B. Moore, 1996, "Impact of the Single Market Programme on the EU Banking and Credit Sectors", Study for ECDGXV, prepared by Institute of European Finance.

Gardener, Edward, Philip Molyneux and B. Moore, 1997a, "The Impact of the Single Market Programme on EU Banking", paper presented at workshop organized by EDI on "Internationalization of Financial Services," August 8, Singapore.

Gardener, Edward, Philip Molyneux and B. Moore, 1997b, "The Impact of the Single Market Programme on EU Banking: Select Policy Experiences for Developing Countries", Institute of European Finance. 
and J. Tepett, 1993, "The impact of 1992 on the Norwegian Financial Services Sector: A Select Duplication Exercise Using the Price Waterhouse/Cecchini Methodology," mimeo, Institute of European Finance.

Gavin, Michael and Ricardo Hausmann, 1996, "Make Or Buy? A Case for Deep Financial Integration," mimeo, Inter-American Development Bank, Washington, D.C., September.

Gelb, Alan and Silvia Sagari, 1990, "Trade in banking services: issues for multilateral negotiations," World Bank, Policy, Research, and External Affairs Working Papers 381.

Glaessner, Thomas and Daniel Oks, 1994, "North American Free Trade Agreement, Capital Mobility, and Mexico Financial System," World Bank, processed, April.

Goldstein, Morris and Philip Turner, 1996, "Banking Crises in Emerging Economies: Origins and Policy Options," BIS Economic Papers, No. 46, October.

Guash, J. Luis and Thomas Glaessner, 1993, "Using Auctions to Allocate and Price Long-Term Credit," World Bank Research Observer, Vol. 8:2, 169-94.

Harris, John R., Fabio Schianterelli, and Miranda G. Siregar, 1994, "How financial liberalization in Indonesia affected firms' capital structure and investment decisions," in Caprio et al. 1994 (Also Country Economics Department, World Bank, 1992, Policy research working papers, No. 997)

Hoekman, Bernard, and Pierre Sauvé, 1994, "Liberalizing Trade in Services," World Bank Discussion Paper 243, World Bank.

Hoekman, Bernard, and Carlos A. Primo Braga, 1997, "Protection and Trade in Services: A Survey," Policy and Research Working Paper, No. 1747, World Bank.

Honohan, Patrick, 1995, "Measuring European Financial Integration: Flows and Intermediation in Greece, Ireland and Portugal," ESRI Working Paper 60, Dublin, Ireland.

Honohan, Patrick, 1997a, "Banking Systems Failures in Developing and Transition Countries: Diagnosis and Prediction," BIS Working Paper, No. 39, January

Honohan, Patrick, 1997b, "Consequences for Greece and Portugal of the Opening-Up of the European Banking Market," draft, The Economic and Social Research Institute, Dublin, Ireland.

IMF, 1997, "Towards a Framework for Sound Banking," main paper and supplement, April, Washington DC. 
Jayaratne, Jith and Philip E. Strahan, 1996, "Entry Restrictions, Industry Evolution and Dynamic Efficiency: Evidence from Commercial Banking," mimeo, Federal Reserve Bank of New York.

Levine, Ross, 1996, "Foreign banks, financial development, and economic growth" in Barfield. , 1997, "Financial Development and Economic Growth," Journal of Economic Literature, June.

Mathieson, Donald and Liliana Rojas-Suarez, 1993, "Liberalization of the Capital Account: Experiences and Issues," IMF Occasional Paper, 102.

McFadden, Catherine, 1994, "Foreign banks in Australia," mimeo, World Bank, processed.

Molyneux, Philip, D.M. Lloyd-Williams and John Thornton, 1994, "Competitive Conditions in European Banking," Journal of Banking and Finance, 18:3, 445-459.

Montes-Negret, Fernando and Luca Papi, 1996, "Are Bank Interest Rate Spreads Too High: A Simple Model for Decomposing Spreads," Public Policy Note for the Private Sector, World Bank

Moshirian, Fariborz, 1994, "What determines the supply of international financial services?" Journal of Banking and Finance, 18:495-504.

Musalem, Alberto, Dimitri Vittas and Asli Demirguc-Kunt, 1993, "North American Free Trade Agreement, Issues on Trade in Financial Services for Mexico," World Bank, Policy and Research working paper No. 1153.

Neven, Darrien J., 1989, "Structural adjustment in European retail banking", Discussion paper no. 311, Centre for European Policy Research, April.

Nicholl, Peter, 1997, "New Zealand's Experience with Foreign Ownership in its Financial System," mimeo, IMF, paper presented at workshop organized by EDI on "Internationalization of Financial Services," August 8, Singapore.

Nolle, Daniel, E. and Rama Seth, 1996, "Do Banks Follow Their Customers Abroad?" Federal Reserve Bank of New York, Research Paper 96-20.

OECD, 1996. "Regulatory Reform in the Financial Services Industry: Where Have We Been? Where Are We Going?," DAFFE/ECO, October, Paris.

Pastor, Jose M., Francisso Perez, and Javier Quesada, 1997, "The Opening of the Spanish Banking System: 1985-1996," mimeo, Universitat de Valencia, September. 
Pearly, Brian, 1997, "Latin American Banks: How Conservative Regulations Help Create Profits," mimeo, Equity Research, JP Morgan, New York.

Peek, Joe, and Eric S. Rosengren, 1997, "The International Transmission of Financial Shocks: The Case of Japan," American Economic Review, Vol. 87, No. 4, September.

Pigott, C.A. "Financial Reform and the Role of Foreign Banks in Pacific-Basin Nations." Financial Policy and Reform in Pacific-Basin Countries, H. Cheng (Ed.). Lexington Books, Lexington, 1986.

Ramos, Roy, 1997a, "Prudential Norms and CAMELOT: How Real are Reported Earnings and Book Values" Banking Research mimeo, Goldman Sachs, Hong Kong, January 8.

Ramos, Roy, 1997b, "Asian Banks at Risk: Solidity, Fragility," Banking Research mimeo, Goldman Sachs, Hong Kong, September 4.

Reisen, Helmut and Bernard Fischer, 1993, Financial Opening: Policy Issues and Experiences in Developing Countries, OECD Development Center, Paris.

Sagari, Silvia, 1989, "International trade in financial services," World Bank, Policy, planning, and research working papers 134 .

, 1986, The Financial Service Industry: An International Perspective, Ph.D.-dissertation, NYU.

Sapir, Andre, 1993, "The Structure of Services in Europe: A Conceptual Framework," European Economy, 3, 83-99.

Sauve, Pierre and Brenda Gonzalez-Hermisollio, 1993, "Financial Services and the North American Free Trade Agreement, Implications for Canadian Financial Institutions," The NAFTA Papers: C.D. Howe Commentary, Toronto, C.D. Howe Institute.

Securities Industry Association, 1997, "Asian Capital Markets: Market Access Restrictions And Regulatory Environment Facing U.S. Securities Firms in Selected Asian Markets," January, Washington, D.C.

Schineller, Lisa, 1997, "An Econometric Model of Capital Flight from Developing Countries," International Finance Discussion Paper, 579, March, Board of Governors of the Federal Reserve Board.

Skipper, Harold D. "International Trade In Insurance." In C. Barfield (ed.), International Financial Markets: Harmonization versus Competition, AEI Press, Washington, D.C., 1996. 
Sorsa, Piritta, 1997, "The GATS Agreement on Financial Services -- A Modest Start to Multilateral Liberalization," IMF Working Paper 97/55, May 1997.

Stiglitz, Joseph and Marilou Uy, 1996, "Financial Markets, Public Policy and the Asian Miracle," The World Bank Research Observer, August, 11:2, 249-76.

Swedlove, Frank and Patricia Evanoff, 1992, "Financial Services in the NAFTA Free Trade Agreement: A Canadian Perspective," Canadian Financial Services Alert, Vol. 2:7, 4958.

Terrell, H.S., 1986, "The Role of Foreign Bank in Domestic Banking Markets," in H. Cheng, ed. Financial Policy and Reform in Pacific-Basin Countries, Lexington: Lexington Books.

Vittas, Dimitri, 1991, "Measuring commercial bank efficiency, use and misuse of bank operating ratios," Policy Research Working Paper 806, World Bank.

Vives, Xavier, 1990, "Deregulation and Competition in Spanish Banking", European Economic Review, Vol. 34, 403-411.

Walter, Ingo, 1985, Barriers to Trade in Banking and Financial Services, Thames, No. 41.

Walter, Ingo, 1987, Global competition in financial services, Washington D.C.: American Enterprise Institute.

Walter, Ingo, 1993, High Performance Financial Systems: Blueprint for Development, ASEAN/ISEAS Current Economic Affairs Series, Singapore.

Wang, Zhen Kun, 1995, "Financial Sector Integration of the Visegrad Countries with the European Union," mimeo, World Bank.

Wengel, Jan ter, 1995, "International trade in banking services," Journal of International Money and Finance, Vol. 14:1, 47-64.

White, Lawrence J. "Competition versus Harmonization: An Overview of International Regulation of Financial Services." In C. Barfield (ed.), International Financial Markets: Harmonization versus Competition, AEI Press, Washington, D.C., 1996.

White, William REFORM., 1996a, "International Agreements in the Area of Banking and Finance: Accomplishments and Outstanding Issues," BIS Working Paper No. 38, Basle, October.

White, William R., 1996b, "Changing Financial Systems in Small Open Economies," BIS Working Paper, Basle, December. 
World Bank, 1995, The Emerging Asian Bond Market, World Bank, Asia and Pacific Region, June.

World Bank, 1997a, Global Development Finance, World Bank, Washington, D.C.

World Bank, 1997b, Private Capital Flows to Developing Countries: The Path to Financial Integration, OUP/WB.

World Bank, 1997c, World Development Indicators World Bank, Washington, D.C.

World Trade Organization, 1997, Opening Markets in Financial Services and the Role of GATS, by Masamichi Kono, Patrick Low, Mukela Luanga, Aaditya Mattoo, Maika Oshikawa and Ludger Schuknecht, September, Geneva. 
Table 1. Integration of Financial Systems of Asia (1995, except where noted)

\begin{tabular}{|c|c|c|c|c|c|c|}
\hline & \multicolumn{2}{|c|}{$\begin{array}{l}\text { Degree of Financial } \\
\text { Integration' }\end{array}$} & \multirow{2}{*}{$\begin{array}{l}\text { Private } \\
\text { External } \\
\text { Debt as } \\
\text { Percent of } \\
\text { GDP }\end{array}$} & \multirow{2}{*}{$\begin{array}{c}\text { Foreign } \\
\text { Bank Share }{ }^{2 f}\end{array}$} & \multirow{2}{*}{$\begin{array}{l}\text { Foreign Share } \\
\text { of Capital } \\
\text { Market Activity } \\
(\%)\end{array}$} & \multirow{2}{*}{$\begin{array}{c}\text { Cross-Border } \\
\text { Financial Services in } \\
\text { Insurance as Percent of } \\
\text { GDP }^{3 /}\end{array}$} \\
\hline & $\begin{array}{l}1985 \text { to } \\
1987\end{array}$ & $\begin{array}{l}1992 \text { to } \\
1994\end{array}$ & & & & \\
\hline Indonesia & Medium & High & $22.9 \%$ & 0.35 & 75 & $0.22 \%{ }^{4 \prime}$ \\
\hline South Korea & High & High & N/A & 0.23 & 6 & $0.30 \%$ \\
\hline Malaysia & High & High & $24.0 \%$ & 0.09 & 50 & $0.009 \% \%^{5 /}$ \\
\hline Philippines & Medium - & High & $10.5 \%$ & 0.46 & 50 & $0.23 \%$ \\
\hline Singapore & $\mathrm{N} / \mathrm{A}$ & N/A & $\mathrm{N} / \mathrm{A}$ & 0.29 & N/A & $1.63 \%$ \\
\hline Thailand & Medium + & High & $26.5 \%$ & 0.08 & 34 & $0.63 \%$ \\
\hline India & Medium & Medium+ & $3.4 \%$ & 0.00 & 25 & $\mathrm{~N} / \mathrm{A}$ \\
\hline
\end{tabular}

Sources: Claessens, Demirguc-Kunt and Huizinga (1997), World Bank (1997), World Development Indicators (WDI, 1997), Global Development Finance (1997).

Notes: $1 /$ The index of financial integration is based on country's access to international financial markets, its ability to attract private external financing, and the level of diversification of its financing (Source: World Bank, 1997).

2/ Ratio of number of reporting foreign banks to total number of reporting banks averaged over the period 1988 to 1995 (Source: Claessens, Demirguc-Kunt and Huizinga, 1997).

3/ Defined as the sum of exports and imports of insurance services as a percentage of GDP (Source: WDI, 1997).

4/ Imports only.

5/ Exports only, 1994. 


\section{Table 2. Derived Actual Operating Costs to Assets (percentages, end 1995)}

\begin{tabular}{|c|c|c|}
\hline & $\begin{array}{c}\text { Derived from } \\
\text { Aggregate Margins }\end{array}$ & Actual Reported $1 /$ \\
\hline Hong Kong & 1.734 & 1.40 \\
\hline Indonesia & -0.746 & 2.67 \\
\hline South Korea & 2.013 & 2.24 \\
\hline Malaysia & 0.568 & 1.37 \\
\hline Philippines ${ }^{2}$ & 2.664 & 3.26 \\
\hline Singapore & N/A & 1.26 \\
\hline Thailand $3 /$ & 2.998 & 1.79 \\
\hline
\end{tabular}

Source: various other data sources. The derived operating cost are calculated by adjusting the difference between aggregate lending and deposit rates (as reported by the respective central bank) for the required rate of return on equity capital (set at 15\%), the effects of inflation (actually reported for 1995), the effect of non-performing loans (as reported by the authorities for the banking system for 1995), and reserve requirements (proxied by the actual amount of reserves held by the banking system at the central bank as a fraction of deposits). The residual would then represent the intermediation costs if the banking system behaved according to the model as capital constrained, optimizing firms. For further detail on the model, see Montes-Negret and Papi (1996),

1/ "Actual Reported" operating costs to assets ratio here is an average of those ratios reported by both foreign and domestic banks (Source: Demirguc-Kunt and Huizinga, 1997)

2/ Applies to domestic Philippine banks only

3/ Applies to domestic Thai banks only 
Table 3. Performance Indicators of Banking Sector ${ }^{1 /}$

\begin{tabular}{lcccc}
\hline & Years over which averaged & $\begin{array}{c}\text { Net Interest Margin } \\
\text { /Total Assets }\end{array}$ & $\begin{array}{c}\text { Overhead/ } \\
\text { Total Assets }\end{array}$ & $\begin{array}{c}\text { Net Profit/ } \\
\text { Total Assets }\end{array}$ \\
\hline Hong Kong & $1990-1995$ & 1.9 & 1.5 & 1.7 \\
Indonesia & $1988-1995$ & 3.5 & 2.9 & 0.9 \\
South Korea & $1991-1995$ & 1.7 & 2.1 & 0.4 \\
Malaysia & $1988-1995$ & 2.4 & 1.6 & 0.9 \\
Philippines & $1988-1995$ & 4.2 & 4.4 & 2.0 \\
Singapore & $1991-1995$ & 1.9 & 1.3 & 1.1 \\
Thailand & $1988-1995$ & 3.1 & 2.0 & 1.1 \\
India & $1992-1995$ & 3.3 & 1.4 & 2.3 \\
Comparators & $1992-1995$ & 1.9 & 2.1 & 0.4 \\
Germany & $1989-1995$ & 1.4 & 1.1 & 0.2 \\
Japan & $1988-1995$ & 3.1 & 3.2 & 0.5 \\
U.S. & & & & \\
\hline \hline
\end{tabular}

Source: Demirguc-Kunt and Huizinga (1997)

1/ Data presented are weighted averages of figures from all reporting banks, domestic and foreign. 
Table 4. Performance Indicators of Securities Markets

(1995, unless otherwise noted)

\begin{tabular}{lcccccc}
\hline & $\begin{array}{c}\text { Settlement } \\
\text { Benchmark }\end{array}$ & $\begin{array}{c}\text { Safekeeping } \\
\text { Benchmark }\end{array}$ & $\begin{array}{c}\text { Operational } \\
\text { Benchmark }\end{array}$ & $\begin{array}{c}\text { GSCS } \\
\text { Index }{ }^{2 /}\end{array}$ & $\begin{array}{l}\text { Cumulative } \\
\text { Transaction } \\
\text { Cost (bps) }\end{array}$ & $\begin{array}{c}\text { Impact of } \\
\text { Com Net Return (\%) }\end{array}$ \\
Hong Kong & 90.2 & 90.1 & 89.1 & 241.07 & 234.27 & 1.63 \\
Indonesia & 73.3 & 88.4 & 88.5 & 246.01 & 395.97 & 2.64 \\
South Korea & 82.7 & 91.0 & 94.1 & 90.32 & 322.80 & 50.05 \\
Malaysia & 80.8 & 90.8 & 92.4 & 185.22 & 337.63 & 3.81 \\
Philippines & 51.7 & 73.5 & 72.7 & 96.68 & 225.38 & 192.63 \\
Singapore & 83.3 & 87.4 & 91.1 & 177.72 & 269.24 & 3.35 \\
Thailand & 82.2 & 91.5 & 89.5 & 63.74 & 283.01 & 8.47 \\
India & 16.8 & 75.0 & $28.0^{3 /}$ & 145.95 & 783.17 & 14.56 \\
\hline \hline
\end{tabular}

Source: GSCS

1/ Benchmarks are average for 1995; GSCS and cumulative cost data as of June 1997.

2/ Alternative dates used as index base for India and Philippines (3/31/93 and 2/28/95, respectively).

3/ Figure applies to 1994. 
Table 5. Performance Indicators of Life Insurance (1993).

\begin{tabular}{lcc}
\hline & Pay-back Ratio & $\begin{array}{c}\text { Operating Expense/ } \\
\text { Premium Income }\end{array}$ \\
\hline \hline Hong Kong & N/A & N/A \\
Indonesia & 133.7 & 29.7 \\
South Korea & 101.8 & 15.0 \\
Malaysia & 93.9 & 43.5 \\
Philippines & 69.6 & 24.3 \\
Singapore & 88.5 & 32.9 \\
Thailand & 71.4 & 41.6 \\
India & N/A & N/A \\
\hline \hline
\end{tabular}

Source: Eguchi (1995) 
Table 6. Structure and Scope of Provision of Financial Services.

Hong Kong Merchant banks with restricted licenses are the only ones allowed to engage in securities underwriting and trade.

India Licensed banks are allowed to participate in issues of securities, including underwriting and placement.

Indonesia Commercial banks are allowed to engage only in trust and foreign exchange activities in addition to deposit and lending business (not clear about securities business for banks).

South Korea Only securities businesses are allowed to be active in dealing, broking, underwriting, securities savings, credit granting. (Only representative offices, branches or joint ventures of foreign securities companies who meet the minimum paid-in capital requirement and have been in the securities business for more than 5 years.)

Malaysia Commercial banks can participate through subsidiaries in merchant banking, stock broking, fund management, etc. (without need for separate dealers license). Only banks in Tier-1 status (well managed and capitalized) can undertake securities borrowing and lending.

Merchant banks engage in underwriting and portfolio management and can also take time deposits above a minimum amount and extend loans.

Philippines Universal banking authority granted to new and existing foreign bank branches (called expanded commercial banking authority).

Singapore Participation in issues of securities through commercial banks and merchant banks is allowed. With regard to trading for own account or for account of customers, commercial banks and merchant banks are required to set up separate subsidiaries.

Thailand Participation in issues of securities, underwriting, asset management by banks are allowed.

Source: Various publications. 
Table 7. Market Structure in Banking and Insurance Sectors

\begin{tabular}{|c|c|c|c|c|c|c|c|c|c|c|}
\hline & & \multicolumn{7}{|c|}{ Banking } & \multirow{2}{*}{\multicolumn{2}{|c|}{$\frac{\text { Insurance }}{\text { No. of Companies }} \frac{\text { (1993 data) }}{}$}} \\
\hline & \multirow[b]{2}{*}{ as of } & No. of & anks & \multicolumn{2}{|c|}{ No. of Branches } & \multicolumn{2}{|c|}{$\frac{\text { Market }}{\text { Concentration }}$} & \multirow{2}{*}{$\begin{array}{c}\text { Share of } \\
\text { State-Owned } \\
\text { Bank Assets } \\
(1994)\end{array}$} & & \\
\hline & & $\begin{array}{c}\text { Foreign/ } \\
\text { Joint }\end{array}$ & Total & $\begin{array}{c}\text { Foreign/ } \\
\text { Joint }\end{array}$ & Total & $\begin{array}{c}\text { No. } \\
\text { of } \\
\text { banks }\end{array}$ & $\begin{array}{l}\text { Share } \\
\text { of CB } \\
\text { assets }\end{array}$ & & $\begin{array}{l}\text { Foreign } \\
\text { Insurer }\end{array}$ & Total \\
\hline Hong Kong & 1995 & 154 & 185 & N/A & $\mathrm{N} / \mathrm{A}$ & N/A & $\mathrm{N} / \mathrm{A}$ & 0 & N/A & N/A \\
\hline Indonesia & 1996 & 41 & 239 & 86 & 5919 & $7^{2 /}$ & $>50 \%$ & 48 & 0 & 140 \\
\hline South Korea & 1995 & 9 & 40 & $\mathrm{~N} / \mathrm{A}$ & N/A & 6 & $65.7 \%^{3 \prime}$ & 13 & 5 & 50 \\
\hline Malaysia & 1995 & 16 & 37 & 144 & 1433 & 6 & $59.4 \%{ }^{4 l}$ & 8 & 10 & 61 \\
\hline Philippines & 1995 & 14 & 47 & 4 & $\sim 3000$ & 6 & $51.5 \%$ & N/A & 12 & 126 \\
\hline Singapore & 1993 & 22 & 35 & 347 & 90 & N/A & $\mathrm{N} / \mathrm{A}$ & 0 & 52 & 141 \\
\hline Thailand & 1996 & 14 & 29 & 14 & 3039 & 6 & $68.5 \%{ }^{5 \prime}$ & 7 & 5 & 75 \\
\hline India & 1996 & 23 & 65 & N/A & 62849 & 9 & $58.7 \%^{6 t}$ & 79 & 0 & 2 \\
\hline
\end{tabular}

Source: various

$1 /$ Percentage share of assets. For India, 1993.

2/ These are the 7 state banks (five state-owned commercial banks, a former development bank, and a former savings bank); as of March 1994 they held $44 \%$ deposits of banking system and $52 \%$ total credits, $50 \%$ of total banking system assets

3/ "Big 6" account for $65.7 \%$ of total South Korean commercial banking assets (mkt. concentration data as of 8/95)

4/ Six largest banks account for $59.4 \%$ of total commercial banking system assets; $>80 \%$ of domestic bank assets

5/ Six largest banks account for $68.5 \%$ of total commercial banking system assets; $74.8 \%$ of domestic bank assets

6/ These nine are all state-owned banks. 
Table 8. Indicators of Financial System Development

\begin{tabular}{lccccc}
\hline & $\begin{array}{c}\text { Credit of } \\
\text { Banking } \\
\text { System as \% of } \\
\text { GDP } \\
(1995)\end{array}$ & $\begin{array}{c}\text { Stock Market } \\
\text { Capitalization } \\
\text { as of GDP } \\
(1996)\end{array}$ & $\begin{array}{c}\text { Stock Market } \\
\text { Trading Value } \\
\text { as \% of Market } \\
\text { Capitalization } \\
(1996)\end{array}$ & $\begin{array}{c}\text { Bond Market } \\
\text { Capitalization } \\
\text { as of GDP } \\
(1994)\end{array}$ & $\begin{array}{c}\text { Bond Trading } \\
\text { Volume as \% } \\
\text { of Market } \\
\text { Capitalization } \\
(1994)\end{array}$ \\
\hline Hong Kong & 284.5 & 280.8 & N/A & 8.7 & N/A \\
Indonesia & 49.8 & 41.2 & 35.3 & 5.8 & 10 \\
South Korea & 69.9 & 25.4 & 127.7 & 24.1 & 43 \\
Malaysia & 131.9 & 315.5 & 56.5 & 56 & 32.6 \\
Philippines & 62.9 & 97.5 & 31.6 & 39.3 & N/A \\
Singapore & 76.2 & 169.0 & 42.81. & 72.4 & N/A \\
Thailand & 136.5 & 54.0 & 44.4 & 13.7 & 9 \\
India & 23.9 & 35.1 & 21.7 & 33.9 & 9 \\
\hline
\end{tabular}

Sources: World Bank (1995, 1997), IFC

1. 1995 figure 
Table 9. Indicators of Institutional Framework (mid-1997, unless otherwise indicated)

\begin{tabular}{|c|c|c|c|c|c|c|c|}
\hline & \multirow{2}{*}{$\begin{array}{c}\text { Bank } \\
\text { Regulatory } \\
\text { Framework }\end{array}$} & \multirow{2}{*}{$\begin{array}{c}\text { Bank } \\
\text { Supervision } \\
\text { Quality }\end{array}$} & \multirow[t]{2}{*}{ Transparency } & \multirow{2}{*}{$\begin{array}{c}\text { GS Fragility } \\
\text { Score ( } 0=\text { best } \\
24=\text { worst })\end{array}$} & \multirow{2}{*}{$\begin{array}{c}\text { GS } \\
\text { CAMELOT } \\
\text { scores } 1 / \\
(1=\text { best, } \\
10=\text { worst) } \\
\end{array}$} & \multicolumn{2}{|c|}{$\begin{array}{c}\text { Non-Performing Loans as } \\
\% \text { of Total Loans }\end{array}$} \\
\hline & & & & & & $\begin{array}{c}\text { BIS } \\
\text { Reported } \\
(1996) \\
\end{array}$ & $\begin{array}{c}\text { GS } \\
\text { Estimated }\end{array}$ \\
\hline Hong Kong & $\begin{array}{l}\text { Very Good, } \\
\text { Improving }\end{array}$ & $\begin{array}{l}\text { Good, } \\
\text { Improving }\end{array}$ & Very Good & 8 & 3.5 & 2.9 & $<2$ \\
\hline Indonesia & $\begin{array}{c}\text { Satisfactory, } \\
\text { Improving }\end{array}$ & $\begin{array}{l}\text { Weak, } \\
\text { Improving }\end{array}$ & Satisfactory & 15 & 4.6 & 10.4 & $\begin{array}{l}17, \text { state } \\
5, \text { private }\end{array}$ \\
\hline South Korea & $\begin{array}{l}\text { Weak, } \\
\text { Improving }\end{array}$ & Fair & $\begin{array}{l}\text { Fair, } \\
\text { Improving }\end{array}$ & 18 & $N / A$ & 0.9 & 6 \\
\hline Malaysia & $\begin{array}{l}\text { Satisfactory, } \\
\text { Improving }\end{array}$ & $\begin{array}{l}\text { Weak, } \\
\text { Improving }\end{array}$ & Satisfactory & 15 & 4.5 & 6.1 & 4 \\
\hline Philippines & Good & Fair & Satisfactory & 13 & 3.7 & $\mathrm{~N} / \mathrm{A}$ & $<3$ \\
\hline Singapore & Very Good & Very Good & Poor & 7 & 4.0 & N/A & $<1$ est. \\
\hline Thailand & $\begin{array}{l}\text { Weak, } \\
\text { Improving }\end{array}$ & Weak & Improving & 22 & 5.2 & 7.7 & $>15$ \\
\hline India & $\begin{array}{l}\text { Satisfactory, } \\
\text { Improving }\end{array}$ & $\begin{array}{l}\text { Fair, } \\
\text { improving }\end{array}$ & $\begin{array}{l}\text { Fair, } \\
\text { Improving }\end{array}$ & 11 & 5.8 & 19.5 & $<13$ \\
\hline
\end{tabular}

Source: BIS (1997), Goldman Sachs (1997a and 1997b)

1/ Goldman Sachs CAMELOT Score for domestic banks only. Weightings for calculation of overall score: $25 \%$ for asset quality; $20 \%$ for management; $15 \%$ for capital adequacy; $15 \%$ for earnings; $5 \%$ for liquidity; 15\% for operating environment; $5 \%$ for transparency. 
Table 10. Degree of Openness Indices (1 most closed, 5 most open)

\begin{tabular}{|l|cc|cc|cc|c|}
\hline & \multicolumn{2}{|c|}{ Banking } & \multicolumn{2}{c|}{ Securities } & \multicolumn{2}{c|}{ Insurance } & $\begin{array}{c}\text { Capital } \\
\text { Controls }\end{array}$ \\
\hline & Commitment & Practice & Commitment & Practice & Commitment & Practice & Practice \\
& & & & & & & \\
Hong Kong & 4.20 & 4.75 & 4.00 & 4.40 & 4.40 & 4.00 & 4.80 \\
Indonesia & 3.15 & 3.20 & 3.50 & 3.00 & 3.10 & 2.60 & 3.60 \\
South Korea & 1.10 & 1.70 & 1.70 & 2.10 & 1.20 & 2.60 & 2.65 \\
Malaysia & 2.40 & 2.40 & 2.50 & 2.50 & 2.10 & 2.10 & 2.80 \\
Philippines & 2.80 & 3.35 & 2.40 & 2.40 & 2.90 & 2.80 & 2.45 \\
Singapore & 2.25 & 2.50 & 2.70 & 2.70 & 4.10 & 4.10 & 4.40 \\
Thailand & 2.95 & 2.85 & 2.00 & 2.00 & 2.80 & 2.80 & 4.20 \\
India & 2.70 & 2.25 & 2.50 & 2.10 & 1.00 & 1.00 & 1.50 \\
\hline Average & 2.69 & 2.88 & 2.66 & 2.65 & 2.70 & 2.75 & 3.30 \\
\hline
\end{tabular}


Figure 1. Foreign Participation in the Banking Sector and Efficiency Measures (1995)
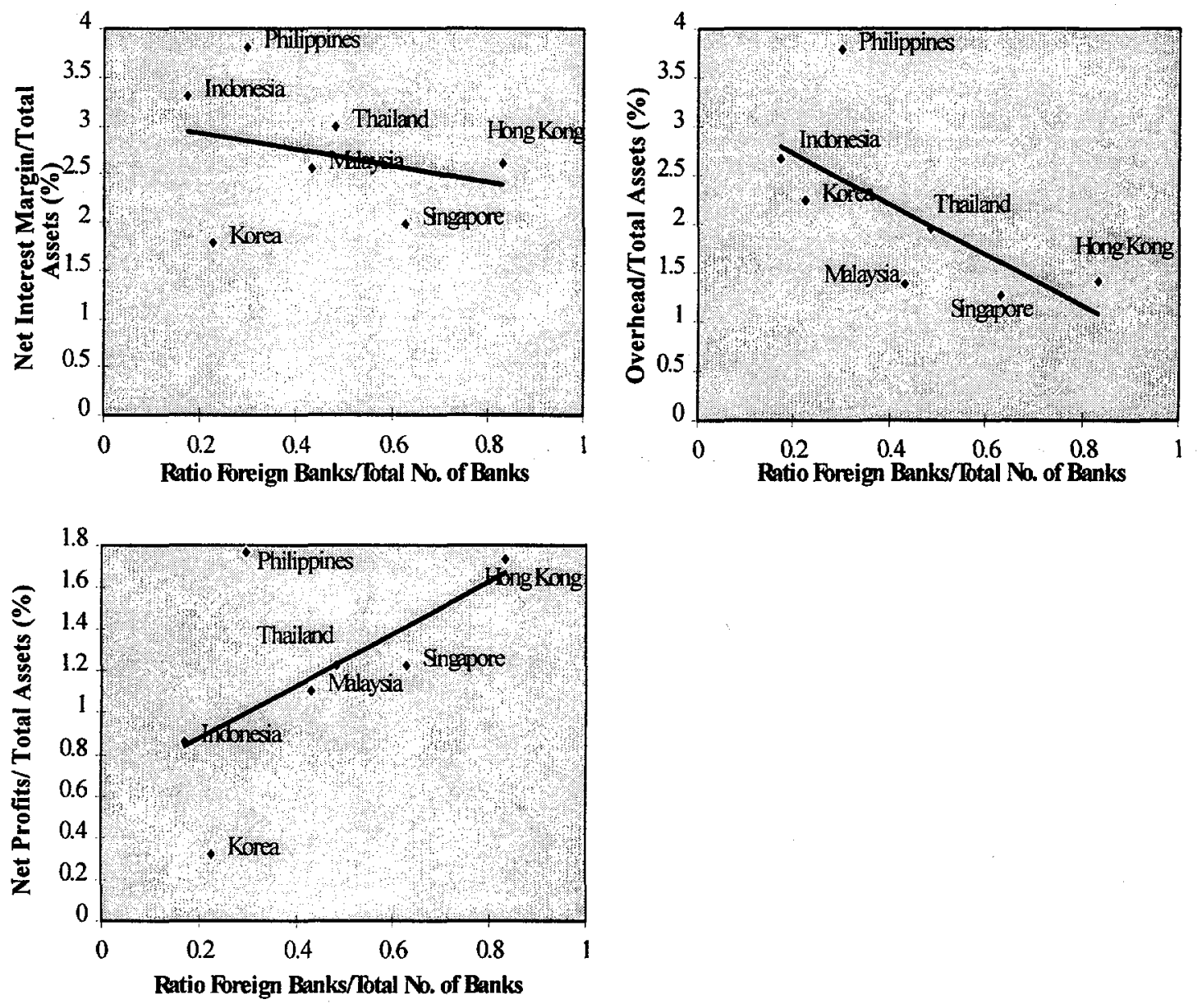

Source: Demirguc-Kunt and Huizinga (1997) for net margins and overhead figures; various sources for number of banks. 1/ Exceptions are Singapore (1993) and Indonesia (1996), as noted in Table 8. 
Figure 2: Foreign Participation in the Banking Sector and Efficiency Measures (1995)
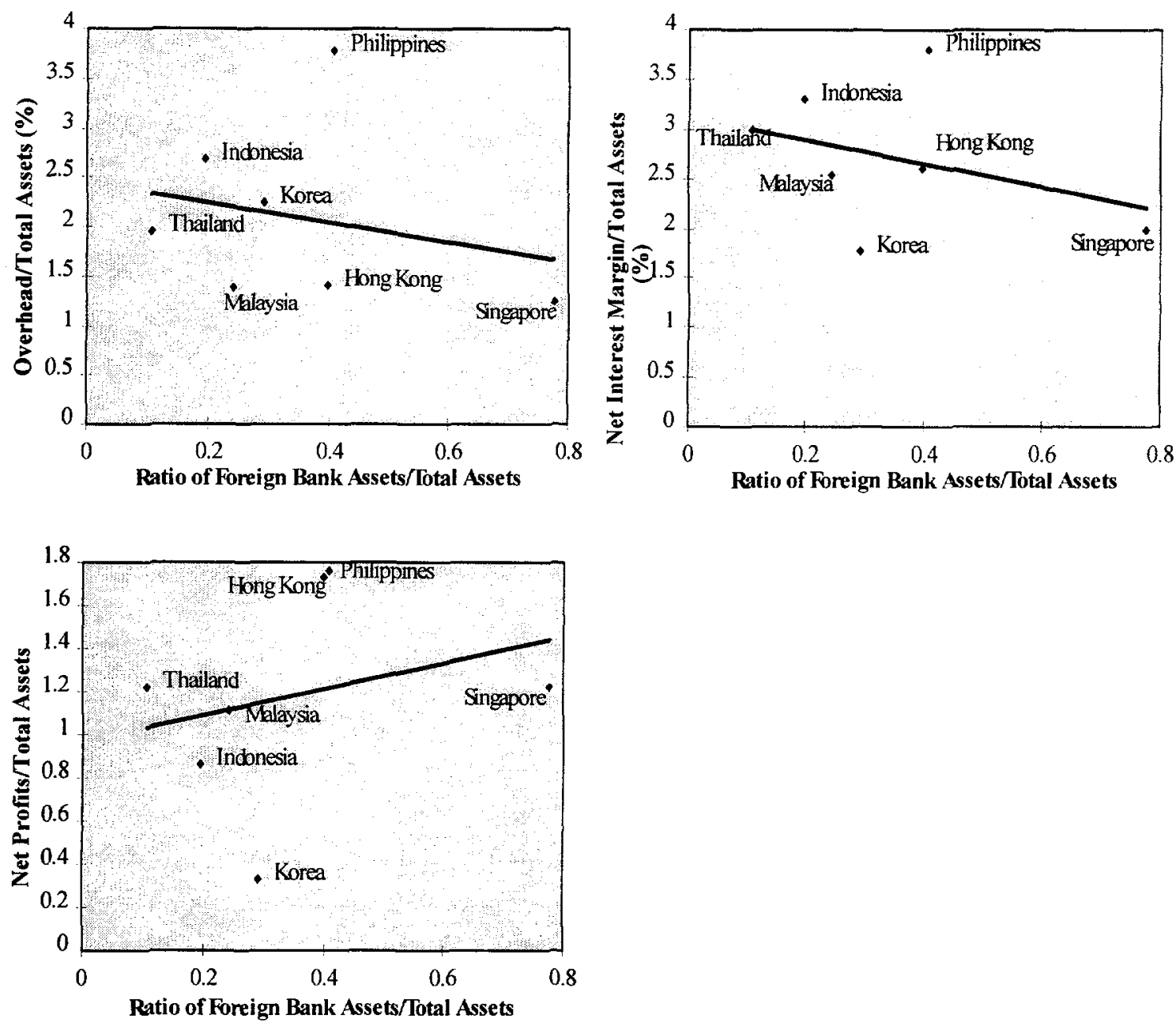

Source: Demirguc-Kunt and Huizinga (1997) for net margins, overhead and asset figures of foreign and domestic banks. 


\section{Figure 3: Openness and Institutional Development and Fragility Measures for the Banking Sector}
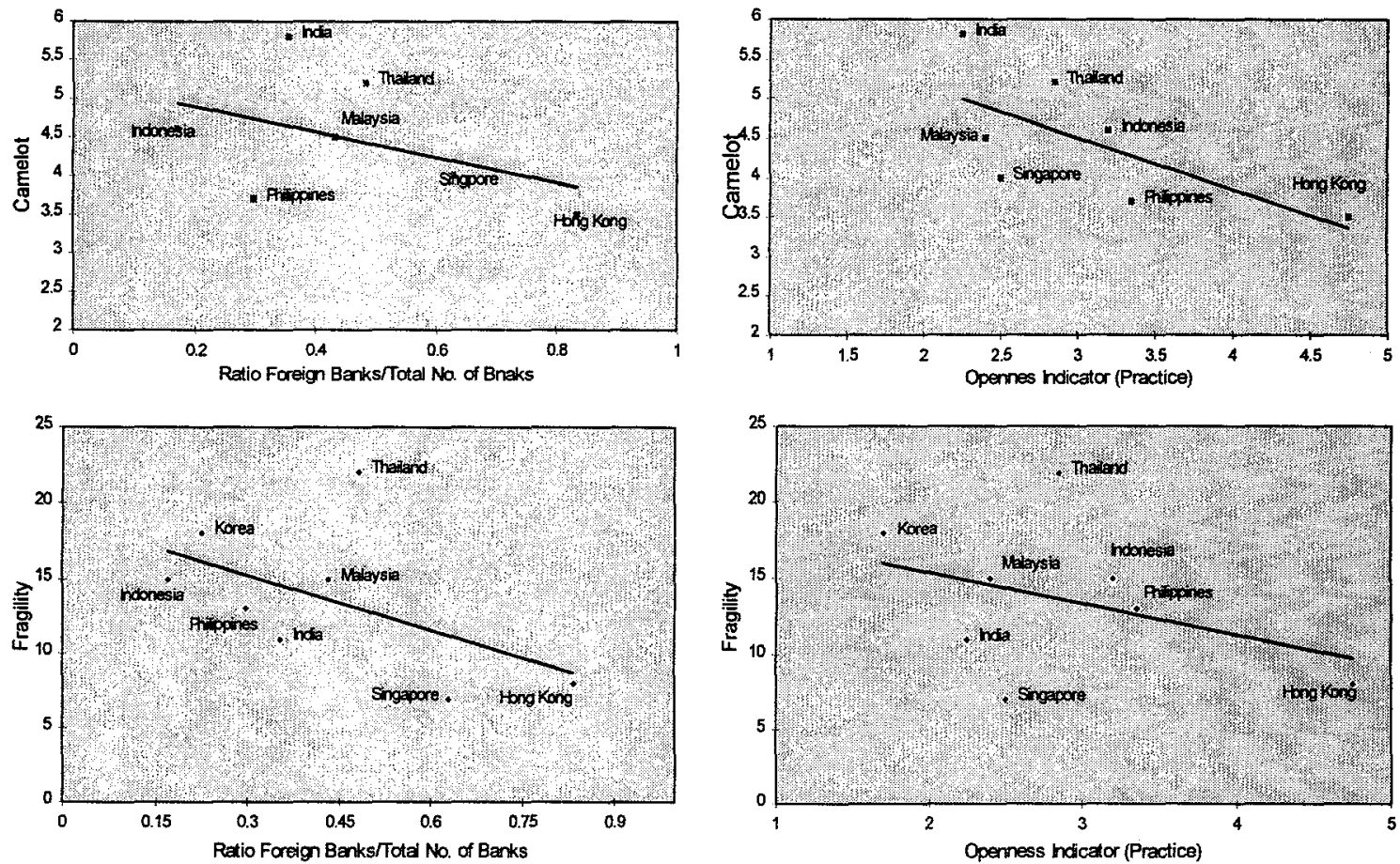

Source: Table 7 for share of foreign banks and Table 9 for institutional development measures. 
Figure 4: Openness and Efficiency Measures of Securities Markets (1995)
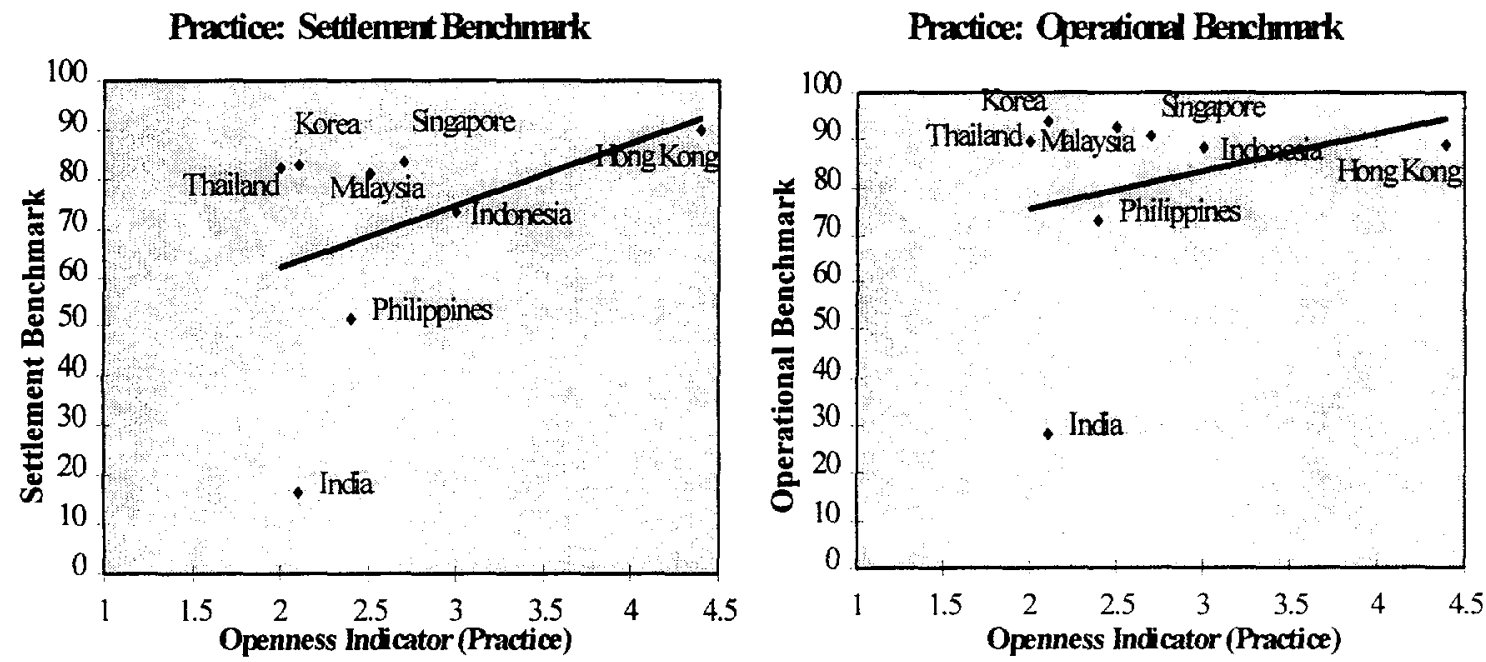

Source: See table 4. 


\section{Figure 5: Openness and Rate of Return and Cost Measures for Securities Markets} (1995)
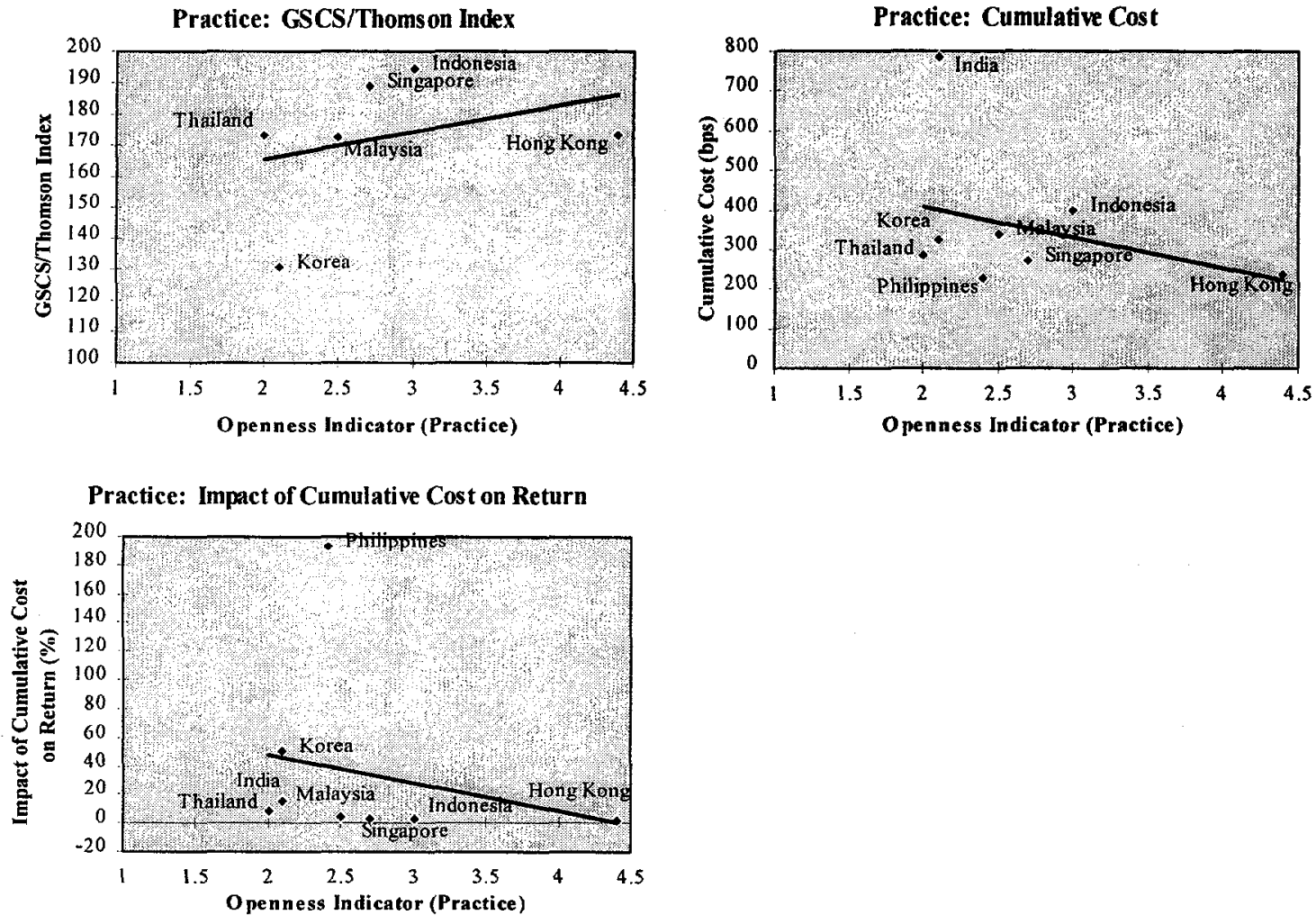

Source: See table 4 
Figure 6. Life-Insurance: Openness and Efficiency Measures (1993)
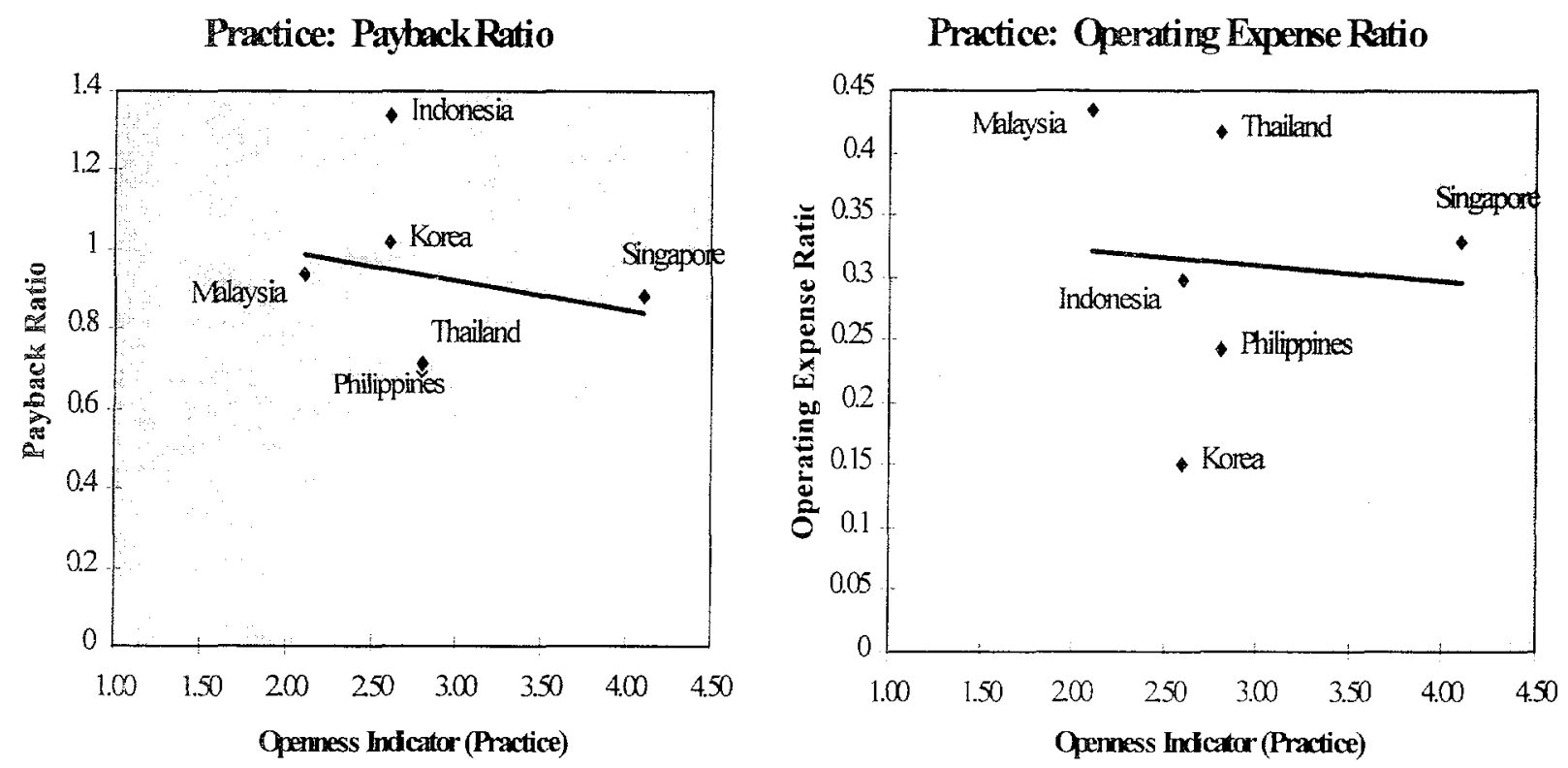

Source: See table 5, 
Criteria: The rankings refer to relative degree of openness only among the eight countries included in the study as of the end of the Financial Services negotiations (mid-1995) or in practice as of end-1996. The rating may comprise one or a combination of features listed below.

A. Establishment and ownership

$5 \quad$ No limits on establishment or equity acquisition/participation in domestic banks/companies; current practice of granting new licenses.

$4 \quad$ Foreign branch establishment(s) permitted to establish within specific limits; allowed foreign equity participation in domestic banks/companies: $51 \%$ and up but less than $100 \%$.

3 No new licenses granted in practice; entry limited to joint ventures only; allowed foreign equity participation in domestic banks/companies of $35-50 \%$.

2 Allowed foreign equity participation in domestic banks/ companies of $15-34 \%$. Economic needs test for foreign broker licenses.

1 Non-prudential government approval required for establishment (minimum limits on amount of DFI, "certain criteria eligibility"); allowed foreign equity participation in domestic banks/companies: above zero - $14 \%$.

B. Offices/ATMs

$5 \quad$ No branch offices nor ATM restrictions.

$4 \quad$ Restrictions on branches of foreign company but none on joint ventures; partial removal of restrictions on additional branches.

3 Restrictions on branches of foreign company; more than 5 ATMs allowed.

2 Extremely tight restrictions on sub-branching; up to 5 offices/ATMs permitted subject to Branches Act; ban on foreign branches from establishing own ATM network; permission from national ATM pool prior to setting-up ATM operations.

$1 \quad$ Non-prudential government approval required for all offices.

C. Lending/activity

$5 \quad$ No limits on lending/business activity; in insurance, market share of $75 \%$ and up.

$4 \quad$ Foreign banks/companies not subjected to directed lending or mandated principal business activity as domestic firms; in insurance, foreign share in domestic market of $61-75 \%$.

3 Restrictions on computation of capital/lending limits or on issuance of securities; requirements on paid-up capital (e.g., higher for FSPs); in insurance, foreign share in domestic market of 31-60\%; limits for issues of/trading to selected securities only or for transactions through established dealers.

2 Specified limits on offshore lending or lending of foreign branches; strict (non-capital) limits on foreign companies vis-à-vis domestic firms; in insurance, foreign share in domestic market of 11$30 \%$; limits on membership to the stock exchange.

1 Restrictions on management and operations such as mandatory lending, transactions only in local currency, ownership of real estate; in insurance, foreign share in domestic market of $1-10 \%$; restrictions on broking; securities trading limited to selected firms; limits on investment trust services to selected establishments; tight regulatory control. 
D. Universal banking

$5 \quad$ No limits on financial services.

4 Some limits on financial activities or approval required.

3 Limits on activities of offices of foreign branches to deposit-taking. Approval required for new products.

2 Limits on foreign branch activities in foreign exchange, credit cards, trust services.

1 Restrictions on all activities normally undertaken by international banks with universal banking rights.

E. Residency requirement

$5 \quad$ No restrictions on composition of board membership; no residency requirement for membership to stock exchange.

$4 \quad$ Restrictions on composition of board membership to at least one national.

3 Restrictions on board membership by foreigners according to proportion of ownership; residency requirement for membership in the stock exchange; locally based CEO; limits on temporary stay of executives.

2 Restrictions on board membership by foreigners to less than one half.

1 Restrictions on board membership by foreigners to one half or more.

F. Cross-border trade

$5 \quad$ Free access to offshore financial instruments; no capital controls.

$4 \quad$ Free access allowed but solicitation or advertising by foreign institutions not permitted.

3 Access to instruments subject to annual limits or access to certain specified products in insurance; registration for borrowing; permission required for participation in issues.

2 Limits on deposit acceptance, offshore borrowing/convertibility; minimum retention requirement for domestic insurers; dealing/trading limited to certain foreign stock exchanges or IPOs limited to residents; overseas investment for institutional investors allowed but subject to restrictions.

1 Controls on cross border supply of all financial services. 


\section{Policy Research Working Paper Series}

Tî́le

WPS1883 Intersectoral Resource Allocation and Fumihide Takeuchi Its Impact on Economic Development Takehiko Hagino in the Philippines

WPS1884 Fiscal Aspects of Evolving Federations: Issues for Policy and Research

WPS1885 Aid, Taxation, and Development: Analytical Perspectives on Aid Effectiveness in Sub-Saharan Africa

WPS1886 Country Funds and Asymmetric information

WPS1887 The Structure of Derivatives Exchanges: Lessons from Developed and Emerging Markets

WPS1888 What Do Doctors Want? Developing Incentives for Doctors to Serve in Indonesia's Rural and Remote Areas

WPS1889 Development Strategy Reconsidered: Mexico, 1960-94

WPS1890 Market Development in the United Kingdom's Natural Gas Industry

WPS1891 The Housing Market in the Russian Federation: Privatization and Its Implications for Market Development

WPS1892 The Role of Non-Bank Financia! Intermediaries (with Particular Reference to Egypt)

WPS1893 Regulatory Controversies of Private Pension Funds

WPS1894 Applying a Simple Measure of Good Governance to the Debate on Fiscal Decentralization

WFS 1895 The Emergence of Markets in the Natural Gas Industry

WPS1896 Congestion Pricing and Network Expansion
Jeffrey A. Franke Sergio L. Schmukler

George Tsetsekos

Panos Varangis

Christopher S. Adam

Stephen A. O'Connell

February 1998

February 1998

C. Bernardo 31148

K. Labrie 31001

February 1998

February 1998

March 1998

Kenneth M. Chornitz Gunawan Setiadi

Azrul Azwar

Nusye Ismail

Widiyarti

Toru Yanagihara

Yoshiaki Hisamatsu

Andrej Juris

Contact for paper

K. Labrie 31001

R. Martin 39065

P. Kokila 33716

T. Charvet 87431

March 1998

K. Labrie 31001

March 1998

S. Vivas 82809

Alla K. Guzanova

March 1998

S. Graig 33160

March 1998

P. Sintim-Aboagye 38526

March 1998

P. Sintim-Aboagye 38526

Jeff Huther

March 1998

S. Valle

84493

Andrej Juris

March 1998

S. Vivas 82809

Thomas-Olivier Nasser 
Policy Research Working Paper Se?is

Title

WPS1897 Deveiopment of Natural Gas and Pipeline Capacity Markets in the United States

WPS1898 Does Membership in a Regional Freferential Trade Arrangement Make a Country More or Less Protectionist?

WPS1899 Determinants of Emerging Market Bond Spread: Do Economic Fundamentals Matter?

WPS1900 Determinants of Commercial Bank Interest Margins and Profitability: Some Intemational Evidence

WPS1901 Reaching Poor Areas in a Federal System

WPS 1902 When Economic Reform is Faster than Statistical Reform: Measuring and Explaining Inequality in Rural China

WPS1903 Taxing Capitai Income in Hungary and the European Union

WPS1904 Ecuador's Rural Noniarm Sector as a Route Out of Poverty

WPS1905 Child Labor in Côte d'Woire: incidence and Determinants

WPS1906 Developing Countries' Participation in the World Trade Organization

WPS1907 Development Experiditures and the Local Financing Constraint

WPS1908 How Dirty Are "Quick and Dirty" Methods of Project Aporaisal?

WPS1909 Capital Market Responses to Environmental Performance in Developing Countries

WPS1910 Capital Ouffiow from the Agriculture Sector in Thailand
Author
จึक
somat
Sor proger?

Andrej Juris

Aach 1988

5. Vives

52500

Faezeh Foroutan

Meroh 4908

1. Tabada 36880

Hong G. Min

Warch 190

Eon

33450

Asli Demirgüç-Kunt

Merch 4988

P. Sintim-Aboagye Harry Huizinga

37858

Martin Ravallion

Warth 1988

P. Sader

32002

Martin Ravalion

March 4998

P. Sader

33902

Jean-Jacques Dethier

Maron 1998

S. Smith

Christoph John

67245

Peter Lanjouw

Merh 1008

P. ienows

34529

Christiaan Grootaert

March 4998

S. Ochieng

31123

Constantine Michalopoulos Aaron 1908

L. Tabada

32896

Albert D. K. Agbonyitor April 4998

L. Somes

s.62:

Dominiquevan de Walle Apll 1998

Dileni Gunewardens

C. Benardo

344.48

Susmita Dasgupta

Apili 1998

R. Yazig:

$37 \div 6$

Niandu Mamingi

Junichi Yamada

April 1908

E. Knire

37471 